\title{
Using brown midrib 6 dwarf forage sorghum silage and fall-grown oat silage in lactating dairy cow rations
}

\author{
M. T. Harper, ${ }^{*}$ J. Oh, ${ }^{*}$ F. Giallongo, ${ }^{*}$ J. C. Lopes, ${ }^{*}$ G. W. Roth, $†$ and A. N. Hristov ${ }^{* 1}$ \\ *Department of Animal Science, and \\ †Department of Plant Science, The Pennsylvania State University, University Park 16802
}

\begin{abstract}
Double cropping and increasing crop diversity could improve dairy farm economic and environmental sustainability. In this experiment, corn silage was partially replaced with 2 alternative forages, brown midrib-6 brachytic dwarf forage sorghum (Sorghum bicolor) or fall-grown oat (Avena sativa) silage, in the diet of lactating dairy cows. We investigated the effect on dry matter (DM) intake, milk yield (MY), milk components and fatty acid profile, apparent total-tract nutrient digestibility, $\mathrm{N}$ utilization, enteric methane emissions, and income over feed cost. We analyzed the in situ DM and neutral detergent fiber disappearance of the alternative forages versus corn silage and alfalfa haylage. Sorghum was grown in the summer and harvested in the milk stage. Oats were grown in the fall and harvested in the boot stage. Compared with corn silage, neutral detergent fiber and acid detergent fiber concentrations were higher in the alternative forages. Lignin content was highest for sorghum silage and similar for corn silage and oat silage. The alternative forages had less than $1 \%$ starch compared with the approximately $35 \%$ starch in the corn silage. Ruminal in situ DM effective degradability was similar, although statistically different, for corn silage and oat silage, but lower for sorghum silage. Diets with the alternative forages were fed in a replicated $3 \times 3$ Latin square design experiment with three 28-d periods and 12 Holstein cows. The control diet contained 44\% (DM basis) corn silage. In the other 2 diets, sorghum or oat silages were included at $10 \%$ of dietary DM, replacing corn silage. Sorghum silage inclusion decreased DM intake, MY, and milk protein content but increased milk fat and maintained energy-corrected MY similar to the control. Oat silage had no effect on DM intake, MY, or milk components compared to the control. The oat silage diet increased apparent total-tract digestibility of dietary nutrients, except starch, whereas the sorghum diet slightly decreased DM, organic matter, crude protein, and starch
\end{abstract}

Received January 4, 2017.

Accepted March 20, 2017

${ }^{1}$ Corresponding author: anh13@psu.edu digestibility. Cows consuming the oat silage diet had higher milk urea $\mathrm{N}$ and urinary urea $\mathrm{N}$ concentrations. Milk $\mathrm{N}$ efficiency was decreased by the sorghum diet. Diet did not affect enteric methane or carbon dioxide emissions. This study shows that oat silage can partially replace corn silage at $10 \%$ of the diet DM with no effect on MY. Brown midrib sorghum silage harvested at the milk stage with $<1 \%$ starch may decrease DM intake and MY in dairy cows.

Key words: dairy cow, forage, oat silage, sorghum silage

\section{INTRODUCTION}

Forage is the most important feed component on dairy farms, and forage shortages can restrict the number of cows that can profitably be milked on a dairy. A fixed land base and annual variation in climatic conditions (e.g., rainfall) are often reasons for a limited amount of forage on farms in the northeastern United States. Additionally, reliance on a few forage crop species, such as corn silage, grown continuously may reduce yields due to weeds, pests, and diseases (Vencill et al., 2012; Gentry et al., 2013). Increasing forage yield by double cropping and improving year-to-year yield stability through crop rotation strategies using a variety of plant species that reduce pest, disease, and climatic risk may increase farm sustainability (Faé et al., 2009; Sindelar et al., 2016). Due to its high concentration of starch, matching the energy content of corn silage is difficult; therefore, variety selection (e.g., brown midrib; BMR) and harvest timing (e.g., boot or soft dough stage) are critical for alternative forage quality as plant OM digestibility can change rapidly. To be adopted on a large scale, alternative forages must be suitable for inclusion not only in heifer and dry cow diets, but also in diets for lactating cows because they consume over $50 \%$ of the feed on a dairy farm. Therefore, alternative forages must be highly digestible to meet the nutrient needs of the modern high-producing dairy cow.

Sorghum and oat silages are 2 forages that have shown potential as alternative forages for lactating dairy cows. Sorghum (Sorghum bicolor) is a C4 warm-season annual grass similar to corn silage, except it has a panicle-type 
seed head with smaller grain kernels, a higher lignin content, and greater yields in low-moisture conditions (Miron et al., 2007). Sorghum roots are toxic to western corn root worm (Diabrotica virgifera virgifera), which can reduce pest pressure on corn if used in a crop rotation (Branson et al., 1969). Brown midrib varieties of sorghum have been developed that have decreased lignin content and increased NDF digestibility (NDFD) compared with traditional varieties (Grant et al., 1995; Oliver et al., 2004). The use of brachytic dwarfing decreases lodging in the low lignin BMR varieties while increasing the leaf-to-stem ratio. The BMR-6 variant of forage sorghum has shown NDFD values higher than the BMR-12 variety and equal to corn silage (Oliver et al., 2004). Yields of sorghum are usually lower than corn in good soil with available moisture, but they can match or exceed corn yields on marginal ground particularly in water-stressed conditions (Aydin et al., 1999; Abdelhadia and Santini, 2006).

Oats (Avena sativa) are a C3 cool-season annual grass that grows well in the cooler temperatures of the spring and fall as part of a double-cropping strategy to increase annual forage yield per unit area. Earlier studies have not found spring-grown oat silage to be as high quality as corn silage (Burgess et al., 1973; Oltjen and Bolsen, 1980). However, fall-grown oats grow quickly and can be harvested in a highly digestible state with relatively high CP content of around $18 \%$ (ContrerasGovea and Albrecht, 2006). Oats do not typically survive northeastern winters and must be harvested in the fall if the goal is inclusion in animal diets. Additionally, oats have the potential to efficiently use fall-applied manure and reduce nitrate leaching (Shepherd, 1999; Di and Cameron, 2002; Carey et al., 2016).

A resilient cropping strategy on a dairy farm would include a diverse variety of alternative forages, although corn silage might still yield over $50 \%$ of the annual forage harvest. Therefore, the hypothesis of this study was that both BMR-6 brachytic dwarf forage sorghum and fall-grown oats could serve as alternative forages to feed in addition to corn silage in lactating dairy cow rations in the northeastern United States. The objectives of the experiment were to partially replace corn silage with either BMR-6 brachytic dwarf sorghum silage or oat silage at $10 \%$ of the diet DM to reflect a theoretical proportion of whole farm alternative forage crop yield, and to investigate the effects on DMI, MY, milk components and fatty acid (FA) profile, nutrient digestibility, $\mathrm{N}$ utilization, enteric methane emissions, and income over feed costs (IOFC) in lactating dairy cows.

\section{MATERIALS AND METHODS}

\section{Crops and Silages}

Brown midrib-6 brachytic dwarf forage sorghum (Alta AF 7202; King's Agriseeds, Ronks, PA) and oats (ForagePlus; Seedway, Hall, NY) were grown in Centre County, Pennsylvania, at approximately $40^{\circ} \mathrm{N}$ on Hagerstown and Hublersburg soils during the summer and fall of 2014. Both crops were planted with a no-till drill (John Deere 1590; Moline, IL) into fields fertilized with $44.8 \mathrm{t} / \mathrm{ha}$ of dairy manure before planting, contributing $42 \mathrm{~kg} /$ ha of ammonium N. Sorghum was planted with $38-\mathrm{cm}$ row spacing, and oats were planted with 19-cm row spacing. A John Deere 946 mower with a roll conditioner was used to mow both crops and, after wilting to around $30 \% \mathrm{DM}$, the forages were gathered and chopped using a John Deere 6750 harvester. Both crops were ensiled without inoculant in 3-m-diameter plastic silage bags (Up North Plastics, Cottage Grove, MN). Sorghum was planted on June 30, 2014, after barley and triticale harvested for forage, at a seeding rate of $7.3 \mathrm{~kg} / \mathrm{ha}$ and fertilized with $67 \mathrm{~kg}$ of $\mathrm{N} / \mathrm{ha}$ from a $30 \%$ urea and ammonium nitrate liquid fertilizer on August 18, 2014. It was mowed on November 10, 2014, at the milk stage of grain development after being partially frost-killed and harvested on November 11, 2014, with a 16-mm theoretical chop length. Oats were planted at a seeding rate of $108 \mathrm{~kg} /$ ha on August 16, 2014, after wheat harvested for grain. The oats were mowed in the boot stage on November 8, 2014, and harvested on November 14, 2014, with a 12-mm theoretical chop length. The corn silage, which was the control in this experiment, was a mixture of the following hybrids: Mycogen TMF2R737 (112-d relative maturity; Mycogen, San Diego, CA), Dekalb DKC 52-61 (102-d relative maturity; DeKalb, St. Louis, MO), and NK N60F-3111 (107-d relative maturity; Syngenta, Basel, Switzerland). Corn silage was grown in Centre County, Pennsylvania, at approximately $40^{\circ} \mathrm{N}$ on Hagerstown and Hublersburg soils and planted between May 1 and May 10, 2014, at a rate of 79,000 seeds/ha. It was planted with a no-till drill (John Deere 1590) into fields fertilized with $44.8 \mathrm{t} / \mathrm{ha}$ of dairy manure before planting, contributing $42 \mathrm{~kg} / \mathrm{ha}$ of ammonium N. An additional $43 \mathrm{~kg} / \mathrm{ha}$ of $\mathrm{N}$ was applied as $30 \%$ urea and ammonium nitrate liquid before planting and $100 \mathrm{~kg} / \mathrm{ha}$ of $\mathrm{N}$ in the same form as a sidedress application. Corn silage harvest was conducted between September 15 and September 30 at a target DM of $38 \%$ with a $19-\mathrm{mm}$ chop length and ensiled in an upright concrete silo. 


\section{Animals and Diets}

All animals were cared for according to procedures approved by The Pennsylvania State University's Institutional Animal Care and Use Committee. Twelve midlactation Holstein dairy cows, 6 primiparous (MY $37 \pm 2.6 \mathrm{~kg} ;$ DIM $100 \pm 6 \mathrm{~d}$; BW $592 \pm 51 \mathrm{~kg}$ ) and 6 multiparous (MY $47 \pm 5.8 \mathrm{~kg} ; 2.3 \pm 0.5$ lactations; DIM $61 \pm 16 \mathrm{~d}$; BW $639 \pm 39 \mathrm{~kg}$ at the beginning of the experiment with two 28-d periods) were used in a replicated $3 \times 3$ Latin square design balanced for residual effects. Each 28-d period consisted of $18 \mathrm{~d}$ of adaptation and $10 \mathrm{~d}$ of data and sample collection. Cows were placed in 4 groups of 3 cows each based on DIM, MY, and parity. Cows within a group were randomly assigned to 1 of 3 diets, as described below. All cows were housed in the tiestall barn of The Pennsylvania State University's Dairy Research and Teaching Center. Diets were mixed and fed from a Rissler model 1050 TMR mixer (I.H. Rissler Mfg. LLC, Mohnton, PA). Cows were fed once daily around $0800 \mathrm{~h}$ to yield approximately 5 to $10 \%$ refusals. Feed was pushed up 3 times throughout the day. The cows were milked twice daily at 0700 and $1800 \mathrm{~h}$.

Three different diets, shown in Table 1, were fed to the cows during the experiment as follows: a control diet (CS), based on corn silage and alfalfa haylage; an oat silage diet (OS), oat silage included at $10 \%$ of dietary DM, replacing $22.7 \%$ of the control diet corn silage DM; and a sorghum silage diet (SS), sorghum silage included at $10 \%$ of dietary DM, replacing $22.7 \%$ of the control diet corn silage DM. The CS diet was formulated to meet or exceed the NRC (2001) requirements for $\mathrm{NE}_{\mathrm{L}}$ and $\mathrm{MP}$ of a cow with $650 \mathrm{~kg} \mathrm{BW}, 44$ $\mathrm{kg} / \mathrm{d} \mathrm{MY}, 3.8 \%$ fat, $3.2 \%$ true protein, and at $27 \mathrm{~kg} / \mathrm{d}$ DMI.

\section{Sampling and Analyses}

Refusals were collected and weighed individually for each cow just before the morning feeding to measure daily as-fed intake. Total mixed ration, refusals, and forage (sorghum, oat, alfalfa, and corn silages) samples were collected twice weekly, composited by week and diet (i.e., silage type), stored at $-20^{\circ} \mathrm{C}$, and then ovendried at $55^{\circ} \mathrm{C}$ for $72 \mathrm{~h}$. At least 2 separate TMR samples were collected during each period and processed individually for particle size analysis using the Penn State Particle Separator with 19-, 8-, and 4-mm sieves. The procedure described in the extension publication by Heinrichs (2013) was used for this analysis. All TMR samples were collected within $1 \mathrm{~h}$ of feeding. The weekly DM content of the TMR and refusals was used to calculate individual daily DMI. Concentrate feeds
Table 1. Ingredient and chemical composition of the diets fed in the experiment

\begin{tabular}{|c|c|c|c|}
\hline \multirow[b]{2}{*}{ Item } & \multicolumn{3}{|c|}{ Diet $^{1}$} \\
\hline & CS & OS & SS \\
\hline \multicolumn{4}{|l|}{ Ingredient, $\%$ of DM } \\
\hline Corn silage & 44 & 34 & 34 \\
\hline Alfalfa haylage $^{2}$ & 7.5 & 7.5 & 7.5 \\
\hline Oat silage & - & 10 & - \\
\hline Sorghum silage & - & - & 10 \\
\hline Hay/straw mixture & 4 & 4 & 4 \\
\hline Cottonseed hulls & 4 & 4 & 4 \\
\hline Ground corn & 11 & 11 & 11 \\
\hline Heat-treated whole soybeans & 7.5 & 7.5 & 7.5 \\
\hline Solvent-extracted canola meal & 7 & 7 & 7 \\
\hline SovPLUS ${ }^{3}$ & 7.5 & 7.5 & 7.5 \\
\hline Molasses ${ }^{4}$ & 4.5 & 4.5 & 4.5 \\
\hline Mineral/vitamin premix ${ }^{5}$ & 3 & 3 & 3 \\
\hline \multicolumn{4}{|l|}{ Composition, $\%$ of DM } \\
\hline $\mathrm{CP}^{6}$ & 16.3 & 16.8 & 16.6 \\
\hline $\mathrm{RDP}^{7}$ & 9.7 & 9.7 & 9.5 \\
\hline RUP $^{7}$ & 6.6 & 7.1 & 7.0 \\
\hline $\mathrm{NDF}^{6}$ & 32.0 & 33.4 & 34.2 \\
\hline $\mathrm{ADF}^{6}$ & 22.2 & 23.3 & 23.7 \\
\hline $\mathrm{NFC}^{7}$ & 44.3 & 41.5 & 41.8 \\
\hline Starch $^{6}$ & 24.3 & 20.8 & 20.9 \\
\hline Fat $^{6}$ & 4.7 & 4.8 & 4.6 \\
\hline $\mathrm{NE}_{\mathrm{L}},{ }^{7} \mathrm{Mcal} / \mathrm{kg}$ & 1.56 & 1.55 & 1.55 \\
\hline $\mathrm{NE}_{\mathrm{L}}$ intake, ${ }^{7} \mathrm{Mcal} / \mathrm{d}$ & 41.6 & 42.1 & 40.2 \\
\hline $\mathrm{NE}_{\mathrm{L}}$ balance, ${ }^{7} \mathrm{Mcal} / \mathrm{d}$ & 4.0 & 4.1 & 3.2 \\
\hline MP balance, ${ }^{7} \mathrm{~g} / \mathrm{d}$ & 406 & 512 & 486 \\
\hline $\mathrm{Ash}^{6}$ & 6.7 & 7.5 & 7.0 \\
\hline $\mathrm{Ca}^{6}$ & 0.8 & 0.8 & 0.8 \\
\hline $\mathrm{P}^{6}$ & 0.4 & 0.4 & 0.4 \\
\hline
\end{tabular}

${ }^{1} \mathrm{CS}=$ corn silage control diet; OS $=$ oat silage diet; $\mathrm{SS}=$ sorghum silage diet.

${ }^{2}$ Alfalfa haylage was $36.0 \% \mathrm{DM}$ and contained (DM basis) $22.1 \% \mathrm{CP}$, $23.4 \% \mathrm{NFC}$, and $41.4 \% \mathrm{NDF}$.

${ }^{3}$ SoyPLUS (West Central Cooperative, Ralston, IA).

${ }^{4}$ Molasses (Westway Feed Products, Tomball, TX).

${ }^{5}$ The mineral/vitamin premix (Cargill Animal Nutrition, Cargill Inc., Roaring Spring, PA) contained (\%, as-is basis) trace mineral mix, 0.86; $\mathrm{MgO}(56 \% \mathrm{Mg}), 8.0 ; \mathrm{NaCl}, 6.4$; vitamin ADE premix (Cargill Animal Nutrition, Cargill Inc.), 0.48; limestone, 37.2; selenium premix (Cargill Animal Nutrition, Cargill Inc.), 0.07; and dry corn distillers grains with solubles, 46.7. Ca, $14.1 \%$; P, 0.39\%; Mg, 4.60\%; K, 0.45\%; S, $0.38 \%$; Se, $6.67 \mathrm{mg} / \mathrm{kg}$; Cu, $358 \mathrm{mg} / \mathrm{kg} ; \mathrm{Zn}, 1,085 \mathrm{mg} / \mathrm{kg} ; \mathrm{Fe}, 188 \mathrm{mg} /$ $\mathrm{kg}$, vitamin A, 262,656 IU/kg; vitamin D, 65,559 IU/kg; and vitamin $\mathrm{E}, 1,974 \mathrm{IU} / \mathrm{kg}$.

${ }^{6}$ Values calculated using the chemical analysis (Cumberland Valley Analytical Services Inc., Maugansville, MD) of individual feed ingredients of the diet.

${ }^{7}$ Estimated based on NRC (2001).

were sampled weekly and stored at $-20^{\circ} \mathrm{C}$ until analysis. Sorghum and oat silages were first ground through a 4-mm screen (for in situ disappearance measurements), then, along with alfalfa haylage, corn silage, and TMR samples, were ground through a 1-mm screen in a Wiley mill (Thomas Scientific, Swedesboro, NJ) and further composited by period on an equal weight basis. Dried composite samples of sorghum, oat, and corn silages were sent to Cumberland Valley Analytical 
Services Inc. (Maugansville, MD) to be analyzed by wet chemistry methods for amylase-treated NDF (Van Soest et al., 1991), ADF (method 973.18; AOAC International, 2000), lignin (Goering and Van Soest, 1970), fat (method 2003.05; AOAC International, 2006), CP (method 990.03; AOAC International, 2000), soluble protein (Krishnamoorthy et al., 1982), starch (Hall, 2009), ethanol-soluble carbohydrates (DuBois et al., 1956), ash (method 942.05; AOAC International, 2000), and minerals (method 985.01; AOAC International, 2000). Fermentation profiles of the corn, oat, and sorghum silages were analyzed by Cumberland Valley Analytical Services Inc. using near infrared reflectance spectroscopy for lactic, acetic, and butyric acids; titratable acidity; and $\mathrm{pH}$. Concentrate feed samples were ground and composited once for the entire experiment. Dried composite concentrate ingredients were analyzed by Cumberland Valley Analytical Services Inc. by wet chemistry methods for $\mathrm{CP}$, amylase-treated NDF, $\mathrm{ADF}$, fat, CP, starch, ash, and minerals (procedures as referenced above), and NFC was calculated using the equation $\mathrm{NFC}=1-\mathrm{CP}-$ fat $-\mathrm{NDF}-$ ash and $\mathrm{NE}_{\mathrm{L}}$ using the equation $\mathrm{NE}_{\mathrm{L}}=0.0245 \times \mathrm{TDN}-0.12$. Concentrations of $\mathrm{CP}, \mathrm{NDF}, \mathrm{ADF}, \mathrm{NFC}, \mathrm{NE}_{\mathrm{L}}$, starch, fat, ash, $\mathrm{Ca}$, and $\mathrm{P}$ in the TMR were calculated based on the individual feed ingredient values and their inclusion levels in the TMR. The diet values of RDP, RUP, and $\mathrm{NE}_{\mathrm{L}}$ balance were calculated based on NRC (2001) at actual DMI, MY, BW, and milk composition of the cows.

Milk weights were automatically recorded at each milking using the Afimilk system (Kibbutz Afikim, Israel). Milk samples for components and FA analysis were collected on 2 consecutive days (4 consecutive milkings) during wk 4 of each period from the p.m. and a.m. milkings (0700 and $1800 \mathrm{~h}$ ). Milk component samples were collected into tubes containing 2-bromo2-nitropropane-1,3-diol and analyzed individually by Dairy One Laboratory (Ithaca, NY) for fat, true protein, MUN, and lactose content using infrared spectroscopy (Milkoscan 4000; Foss Electric, Hillerød, Denmark). Milk samples for FA analysis from the 4 milkings for each period and cow were collected without preservative and frozen at $-20^{\circ} \mathrm{C}$ until composited based on MY so that a single composited sample was analyzed per cow and per period following the procedure described by Rico and Harvatine (2013). Body weight was recorded daily upon exiting the milking parlor using an AfiFarm 3.04E scale system (S.A.E. Afikim, Rehovot, Israel) for periods 1 and 2. During period 3, BW was not measured because of a scale system malfunction.

During wk 4 of each period, urine and fecal samples were collected for digestibility and $\mathrm{N}$ utilization estimates. Spot urine and fecal samples (approximately
$300 \mathrm{~mL}$ and $500 \mathrm{~g}$ per sample, respectively) were collected 8 times over $3 \mathrm{~d}$ at (d 1) 0500, 1200, and 1800 h; (d 2) 0000, 0900, 1500, and $2100 \mathrm{~h}$; and (d 3) 0300 $\mathrm{h}$ to obtain a representative sample of a 24 -h period. A full description of the urine and fecal sample processing and analyzing can be found in Lee et al. (2012). Briefly, raw urine from each sampling was acidified, diluted, and composited by cow and period and then frozen at $-20^{\circ} \mathrm{C}$ for later analysis of allantoin, uric acid, creatinine, urea $\mathrm{N}$, and total $\mathrm{N}$. Allantoin was analyzed following the procedure by Chen et al. (1992). Stanbio Laboratory (Boerne, TX) kits were used to analyze uric acid (Uric Acid Kit 1045), creatinine (Creatinine Kit 420 ), and urea N (Urea Nitrogen Kit 580). Total N was analyzed in freeze-dried urine samples of 1:10 diluted and acidified urine using a Costech ECS $4010 \mathrm{C} / \mathrm{N} / \mathrm{S}$ elemental analyzer (Costech Analytical Technologies Inc., Valencia, CA). Fecal samples were oven-dried at $65^{\circ} \mathrm{C}$, ground through 1-mm screen in a Wiley mill, and analyzed for DM, OM, CP, starch, NDF, and ADF. A Mixer Mill MM 200 (Retsch GmbH, Haan, Germany) was used to pulverize a 0.5 -g aliquot of fecal sample for $\mathrm{CP}$ analysis $(\mathrm{N} \times 6.25)$ using the Costech ECS 4010 $\mathrm{C} / \mathrm{N} / \mathrm{S}$ elemental analyzer. Starch analysis of fecal DM for apparent total-tract digestibility was performed using a procedure based on the method that included acetate buffer described by Hall (2009). Briefly, starch was gelatinized with $50 \% \mathrm{NaOH}$, incubated for $16 \mathrm{~h}$ at $55^{\circ} \mathrm{C}$ with acetate buffer and amylase, centrifuged, plated on a 96-well plate, and then reacted with a glucose oxidase-peroxidase enzyme solution (P7119; Sigma-Aldrich, St. Louis, MO) for 45 min before being read at $450 \mathrm{~nm}$. Neutral detergent fiber and ADF were analyzed with an Ankom 200 fiber analyzer (Ankom Technology Corp., Macedon, NY) based on the procedures of Van Soest et al. (1991) with $\alpha$-amylase and sodium sulfite in the NDF analysis. A 10-d ruminal incubation was used to determine the indigestible NDF (iNDF; Huhtanen et al., 1994 as modified by Lee et al., 2012) of both feces and TMR, which was used as a marker to estimate apparent total-tract digestibilities of dietary nutrients.

Enteric $\mathrm{CH}_{4}$ and $\mathrm{CO}_{2}$ emissions were measured during wk 4 of each period with the GreenFeed system (C-Lock Inc., Rapid City, SD). Measurements were collected 8 times over $3 \mathrm{~d}$ at 0900, 1500, 2100, 0300, $1200,1800,0000$, and $0500 \mathrm{~h}$ to obtain a representative sample of a 24-h period. Gas sampling procedures followed those recommended by Hristov et al. (2015). Gas measurements of at least 2 min in length per sampling were used in the final statistical analysis, which occurred for $81.3 \%$ of the measurements. Gas emission data were averaged by cow and period for the statistical analysis. 


\section{In Situ}

Ruminal disappearance of DM and NDF from the sorghum and oat silages and separate alfalfa haylage and corn silage samples was determined in situ. The sorghum and oat silage samples were from the current experiment, whereas the corn silage and alfalfa haylage forage samples were from a similar experiment conducted 4 mo after the current experiment (Harper et al., 2017, companion study). Corn silage was $38.5 \%$ $\mathrm{DM}$ and contained (DM basis) $6.4 \% \mathrm{CP}, 46.6 \% \mathrm{NFC}$, $34.5 \%$ starch, and $41.0 \%$ NDF. Alfalfa haylage was $46.0 \% \mathrm{DM}$ and contained (DM basis) $21.0 \% \mathrm{CP}, 24.0 \%$ NFC, and $44.2 \%$ NDF. The nutrient composition of the sorghum and oat silages is in Table 2. Six ruminally cannulated lactating Holstein cows averaging DMI 24.4 $\pm 2.4 \mathrm{~kg}, \mathrm{MY} 36.8 \pm 2.9 \mathrm{~kg}, 2.2 \pm 0.4$ lactations, DIM $148 \pm 10 \mathrm{~d}$, and BW $616 \pm 40.7 \mathrm{~kg}$ were used for the in situ incubations. Cows were fed (\% DM basis) corn silage, 38.33 ; alfalfa haylage, 13.83 ; grass hay and straw mixture, 4.17; ground corn, 9.58; canola meal, 9.58; cookie meal, 5.33; roasted soybeans, 5.00; molasses, 5.00; whole cotton seed, 4.58; cracked corn, 2.50; and mineral mix, 2.10. Oven-dried forages were ground through a 4-mm sieve in a Wiley mill. Approximately $7 \mathrm{~g}$ of each sample was weighed into $10 \times 20 \mathrm{~cm}$ nylon bags with $50-\mu \mathrm{m}$ porosity (Ankom Technology Corp.) and closed with a ziptie after folding. Triplicate bags were sequentially incubated in each cow for $12,24,48$, 72 , and $96 \mathrm{~h}$ and simultaneously removed. Two bags per forage were made for the 0-h time point and processed as the incubated samples with the exception of the rumen incubation step. Upon removal from the rumen, bags were rinsed 3 times with cold water in a washing machine set to agitate for $6 \mathrm{~min}$ each rinse. The zipties were cut off, and any remaining particles were rinsed off with cold tap water. Rinsed bags were then oven-dried for $72 \mathrm{~h}$ at $55^{\circ} \mathrm{C}$ before weighing for DM determination. Samples were composited by silage, time point, and cow before NDF analysis as previously described. Ruminal disappearance was calculated based on initial dry weight of the incubated sample, residue dry weight, and NDF concentration of initial sample and bag residue. Degradation curves were fit to the equation $p=a+b\left(1-\mathrm{e}^{-c t}\right)$ where $p$ is the degraded fraction (of DM or NDF) at time $t, a$ is the soluble fraction, $b$ is the potentially degradable fraction, and $c$ is the rate of degradation of the $b$ fraction (Ørskov and McDonald, 1979). The effective degradability (ED) was determined with the following equation (Ørskov and McDonald, 1979): $\mathrm{ED}=a+b[c \div(c+k)]$, where $k$ is the rate of passage assumed to be $0.03 / \mathrm{h}$. Corn silage NDF degradability did not fit the Ørskov and McDonald model and so was fit with a linear model.
Therefore, corn silage NDF degradability was not statistically compared with the other forages.

\section{Income Over Feed Costs}

Income over feed costs for the 3 diets was calculated using the Pennsylvania State Extension Dairy Team IOFC Tool (Penn State Extension, 2015). The cash flow spreadsheet from the Pennsylvania State Extension Dairy Team (Penn State Extension, 2016) was used to calculate forage monetary values for the IOFC tool. The model dairy included 34.4 ha cropland, 65 lactating cows, 10 dry cows, 52 heifers, and 12 calves. It was assumed that only the forages were grown on the farm, whereas concentrates were purchased. The lactating cow ration was changed in the scenarios to reflect the treatment diet, whereas diets for other cow groups (e.g., dry cows, heifers, and calves) were kept the same among scenarios. First, the total amount of the different forages required for each scenario was calculated. Next, the hectares needed to produce that amount was found by dividing the total amount of each crop needed by the per hectare crop yields obtained for the forages used in the trial. The corn silage yield when double cropped with oats was decreased by $4.9 \mathrm{t}$ of $\mathrm{DM} /$ ha to account for the lower yield of short season corn, which would have to be planted before oats. An additional scenario was run in which a sorghum yield of $13.4 \mathrm{t}$ of $\mathrm{DM} /$ ha was used to show a more typical yield based on timely planting. Then, the variable costs of seed, fertilizer, and herbicide per acre for each crop during 2014 was entered into the spreadsheet. Along with the input costs and the yield information for each crop, the fixed costs were allocated among the forages based on the labor used to produce them to determine price per ton. Milk and components yield from the current study was used with the average milk pricing in Pennsylvania for 2015 to generate the income side of the IOFC equation.

\section{Statistical Analysis}

Statistical analyses for all but the in situ data were run using the MIXED procedure of SAS v9.4 (SAS Institute Inc., Cary, NC). Cow was the experimental unit. Milk yield and DMI from the last $10 \mathrm{~d}$ of the experiment were analyzed with day as a repeated measure. The statistical model included diet, day, period, and period $\times$ diet and diet $\times$ day interactions. Square and cow within square were random effects with all others fixed. Milk composition and FA, nutrient intake, digestibility, $\mathrm{N}$ utilization, and methane and $\mathrm{CO}_{2}$ emissions data were analyzed using the same model without day and diet $\times$ day interaction. Milk composition data were weighted averages based on the MY at each milking. 
Particle size distribution of the 3 TMR was analyzed by sieve size with the MIXED procedure including diet, period, and diet $\times$ period interaction in the model. Silage nutrient composition was compared using the MIXED procedure with silage type in the model. Significance was declared at $P \leq 0.05$ and tendency was declared at $0.05<P \leq 0.10$. If not indicated otherwise, data are presented as least squares means.

Ruminal in situ degradation of DM and NDF was analyzed using the NLMIXED procedure of SAS. The overall regression curve and the individual parameters $(a, b, c$, and $\mathrm{ED})$ were contrasted among forages and significance was declared at $P \leq 0.05$.

\section{RESULTS AND DISCUSSION}

Differences among diets (Table 1) resulted from compositional differences in oat, sorghum, and corn silages (Table 2). As corn silage was replaced on a weight basis, the diets were not isonitrogenous or isocaloric. As indicated earlier, the control CS diet was formulated before the study to meet or exceed NRC (2001) requirements of the cows at the beginning of the experiment. Cows, however, produced less milk with a lower true protein content during the experiment. Therefore, MP supply exceeded requirements for all diets. Crude protein concentration was numerically highest for OS, intermediate for SS, and lowest for CS, following the ranking of $\mathrm{CP}$ concentration in oat, sorghum, and corn silages. Soluble CP was also higher $(P<0.001)$ in the oat and sorghum silages than the corn silage. Neutral detergent fiber and ADF content numerically increased from CS to OS to SS. Starch was numerically lower in OS and SS compared with CS, but $\mathrm{NE}_{\mathrm{L}}$ balance was similar and positive for all diets.

In the current study, the intention was to harvest the sorghum silage at the soft dough stage after starch was deposited in the grain. However, a late planting prevented adequate crop development before a killing frost, which forced a harvest at the milk stage before starch deposition. This resulted in a lower than expected yield of $8.13 \mathrm{t}$ of $\mathrm{DM} /$ ha and almost nonexistent starch concentrations in the sorghum silage. In contrast, Oliver et al. (2004) reported a yield of $9.7 \mathrm{t}$ of $\mathrm{DM} / \mathrm{ha}$ with $16.8 \%$ starch for BMR-6 sorghum harvested at a late dough stage. This highlights the importance of management, particularly prompt planting, in the use of alternative forages. Oats yielded $4.79 \mathrm{t}$ of $\mathrm{DM} / \mathrm{ha}$ and corn silage varieties had an average yield of $18 \mathrm{t}$ of $\mathrm{DM} /$ ha. The DM content of all silages was between 30 and $40 \%$. Oat and sorghum silages had $\mathrm{pH}$ of around 4.5 , which is typical for grass silages. Titratable acidity matched the levels of total acid in both silages. Lactic acid was low in the sorghum silage. Lactic and acetic

Table 2. Nutrient composition and fermentation profile of oat and sorghum silages (\% of DM or as indicated $)^{1}$

\begin{tabular}{|c|c|c|c|c|c|}
\hline \multirow[b]{2}{*}{ Item } & \multicolumn{3}{|c|}{ Silage } & \multirow[b]{2}{*}{$\mathrm{SEM}^{2}$} & \multirow{2}{*}{$\frac{P \text {-value }}{\text { Silage }}$} \\
\hline & Corn & Oat & Sorghum & & \\
\hline $\mathrm{DM}, \%$ & 39.1 & 31.6 & 31.4 & - & - \\
\hline $\mathrm{NDF}$ & $40.2^{\mathrm{c}}$ & $54.7^{\mathrm{b}}$ & $62.7^{\mathrm{a}}$ & 2.25 & 0.001 \\
\hline $\mathrm{ADF}$ & $25.9^{\mathrm{b}}$ & $36.3^{\mathrm{a}}$ & $40.8^{\mathrm{a}}$ & 1.49 & 0.001 \\
\hline Lignin & $3.70^{\mathrm{b}}$ & $2.86^{\mathrm{b}}$ & $4.89^{\mathrm{a}}$ & 0.319 & 0.01 \\
\hline Fat & $3.38^{\mathrm{a}}$ & $3.86^{\mathrm{a}}$ & $1.70^{\mathrm{b}}$ & 0.172 & $<0.001$ \\
\hline $\mathrm{CP}$ & $6.83^{\mathrm{c}}$ & $11.7^{\mathrm{a}}$ & $9.50^{\mathrm{b}}$ & 0.199 & $<0.001$ \\
\hline Soluble protein & $4.10^{c}$ & $8.07^{\mathrm{a}}$ & $5.40^{\mathrm{b}}$ & 0.332 & $<0.001$ \\
\hline Starch & $34.7^{\mathrm{a}}$ & $0.27^{\mathrm{b}}$ & $0.80^{\mathrm{b}}$ & 0.863 & $<0.001$ \\
\hline Ethanol-soluble carbohydrates & $1.17^{\mathrm{b}}$ & $1.77^{\mathrm{b}}$ & $3.70^{\mathrm{a}}$ & 0.455 & 0.02 \\
\hline Ash & $3.47^{\mathrm{c}}$ & $11.2^{\mathrm{a}}$ & $5.70^{\mathrm{b}}$ & 0.600 & $<0.001$ \\
\hline $\mathrm{Ca}$ & $0.20^{\mathrm{c}}$ & $0.60^{\mathrm{a}}$ & $0.41^{\mathrm{b}}$ & 0.005 & $<0.001$ \\
\hline $\mathrm{P}$ & $0.24^{\mathrm{b}}$ & $0.39^{\mathrm{a}}$ & $0.24^{\mathrm{b}}$ & 0.014 & $<0.001$ \\
\hline $\mathrm{K}$ & $1.21^{\mathrm{b}}$ & $4.73^{\mathrm{a}}$ & $1.62^{\mathrm{b}}$ & 0.337 & $<0.001$ \\
\hline $\mathrm{pH}^{3}$ & $3.83^{\mathrm{c}}$ & $4.71^{\mathrm{a}}$ & $4.31^{\mathrm{b}}$ & 0.054 & $<0.001$ \\
\hline \multicolumn{6}{|l|}{ Fermentation acids } \\
\hline Lactic $^{3}$ & $5.43^{\mathrm{b}}$ & $7.27^{\mathrm{a}}$ & $2.28^{\mathrm{c}}$ & 0.347 & $<0.001$ \\
\hline Acetic $^{3}$ & 0.98 & 2.10 & 1.57 & 0.526 & 0.38 \\
\hline Butyric $^{3}$ & $0.0^{\mathrm{b}}$ & $0.88^{\mathrm{a}}$ & $\mathrm{NA}^{4}$ & 0.144 & 0.01 \\
\hline Titratable acidity, ${ }^{3} \mathrm{mEq} / 100 \mathrm{~g}$ & 5.32 & 5.96 & 3.66 & 0.455 & 0.06 \\
\hline
\end{tabular}

${ }^{\mathrm{a}-\mathrm{c}}$ Means within the same row without a common superscript differ $(P<0.05)$.

${ }^{1}$ Three composite samples per silage, one for each experimental period were analyzed (Cumberland Valley Analytical Services Inc., Maugansville, MD).

${ }^{2}$ Largest SEM published in table; $\mathrm{n}=9$ ( $\mathrm{n}$ represents the number of observations used in the statistical analysis).

${ }^{3}$ Analyzed by near infrared spectroscopy.

${ }^{4} \mathrm{NA}=$ not analyzed. 
acids in the oat silage fell within normal values according to the Dairy One Interactive Feed Composition Library (http://dairyone.com/analytical-services/ feed-and-forage/feed-composition-library/interactivefeed-composition-library/; accessed February 28, 2017). Butyric acid was detected above $0.5 \%$ in the oat silage, possibly indicating an extended fermentation process partly due to wetter harvested material. Wilting oats is a challenge in cool fall weather. Both sorghum and oat silages contained starch concentrations below $1 \%$. Oat silage had higher $(P<0.001) \mathrm{K}$ and sorghum silage had a higher concentration $(P=0.02)$ of ethanol soluble carbohydrates (i.e., sugars) than the other silages.

Dry matter intake was not different between CS and OS diets; however, DMI was decreased $(P=0.02)$ in the SS diet. In this experiment, we substituted part of the ration corn silage with 1 of 2 low-starch forages that did not contain developed grain. Corn silage routinely contains starch concentrations above $30 \%$ and could be considered part concentrate and part forage (Boivin et al., 2013). Dry matter intake of high-producing dairy cows can be limited by rumen fill, which may present a challenge in meeting energy demands (Allen, 2000). Rumen fill is also positively related to NDF content of the diet (Allen, 2000). Nichols et al. (1998) demonstrated that increasing dietary NDF concentrations for dairy cows decreased DMI. Oltjen and Bolsen (1980) showed that increasing diet ADF content in growing steers decreased DMI. Diets with less digestible fiber cause rumen fill at lower DMI than diets with more highly digestible fiber (Allen, 2000; Mertens, 2009).

The sorghum silage in this experiment had greater NDF, ADF, and lignin content than the corn silage, which was also observed in other studies comparing BMR sorghum with corn silage (Oliver et al., 2004; Bernard and Tao, 2015). The higher concentration of less digestible fiber in the sorghum silage likely explains the lower DMI of the SS diet, resulting from slower digestion and passage rate and increased ruminal fill. The OS diet was likewise higher in NDF and ADF than the CS diet, but it contained less lignin and had more digestible NDF. The increased digestibility of the oat silage NDF versus corn silage NDF potentially limited the effects of ruminal fill in OS. This outcome resulted in similar DMI between OS and CS. However, OS resulted in only a slight numerical increase in NDF intake as a percentage of BW over SS. Furthermore, OS and SS had the same intake of forage NDF as a percentage of BW $(1.08 \%)$ at different DMI. This finding agrees with Mertens (2009), who proposed that NDF content was the major intake-limiting factor at high DMI, with NDFD altering intake to a lesser extent. Therefore, the difference in NDF concentration between oat silage and sorghum silage may have contributed more to the change in DMI than the difference in NDFD.

The ruminal in situ results (Table 3) compare the alternative forages of this study with corn silage and alfalfa haylage from another study, thus direct conclusions cannot be made regarding the corn silage and alfalfa haylage from the current experiment. However, the nutrient profiles of the 2 sets of conventional forages were similar, and the results seem to support the argument that sorghum silage caused rumen fill limitation of DMI at lower intakes partly because of its lower degradability. In contrast, oat silage intake may have been regulated by energy demand because its greater degradability should have allowed a higher NDF intake, although as previously discussed, the NDF intakes for OS and SS were not different. Dry matter in situ disappearance regression curves for alfalfa haylage, corn silage, oat silage, and sorghum silage are presented in Figure 1. The DM disappearance (i.e., degradability) curve differed $(P<0.001)$ among forages (Figure 1$)$. Corn silage had the highest $(P<0.01)$ percent soluble $\mathrm{DM}$, caused by its high starch content, followed by oat silage, alfalfa haylage, and sorghum silage (Table $3)$. The potentially degradable fraction of DM (b) was higher $(P \leq 0.002)$ for oat and sorghum silage than for alfalfa haylage. Alfalfa haylage had the highest $(P<$ 0.001 ) rate of degradation of the $b$ fraction followed by oat silage, sorghum silage, and corn silage. Corn silage also had the highest $(P=0.002) \mathrm{ED}$ for DM followed closely by oat silage, then alfalfa haylage, and lastly, sorghum silage (Table 3). The oat silage had a more rapid rate of DM degradation than corn silage and similar ED, which may have caused similar rumen fill and DMI. The lower rumen disappearance of sorghum silage DM, may have led more rapidly to rumen fill and lower DMI.

Neutral detergent fiber in situ disappearance curves for alfalfa haylage, oat silage, sorghum silage, and corn silage are shown in Figure 2. Alfalfa had the highest $(P$ $<0.001$ ) soluble NDF fraction compared with oat and sorghum silages (Table 3$)$. The highest $(P<0.001)$ potentially degradable NDF fraction was in the oat silage followed by sorghum silage, and the lowest was in the alfalfa haylage (Table 3$)$. A tendency $(P=0.06)$ existed for alfalfa haylage to have a higher degradation rate than sorghum silage (Table 3). Effective degradability of NDF was higher $(P<0.001)$ in oat silage than either alfalfa haylage or sorghum silage. The higher disappearance of oat silage NDF resulted in higher ED of NDF compared with the sorghum silage, which was reflected in higher DMI for OS compared with SS.

The increased degradability of the oat silage may have come from the delayed maturity related to its fall 


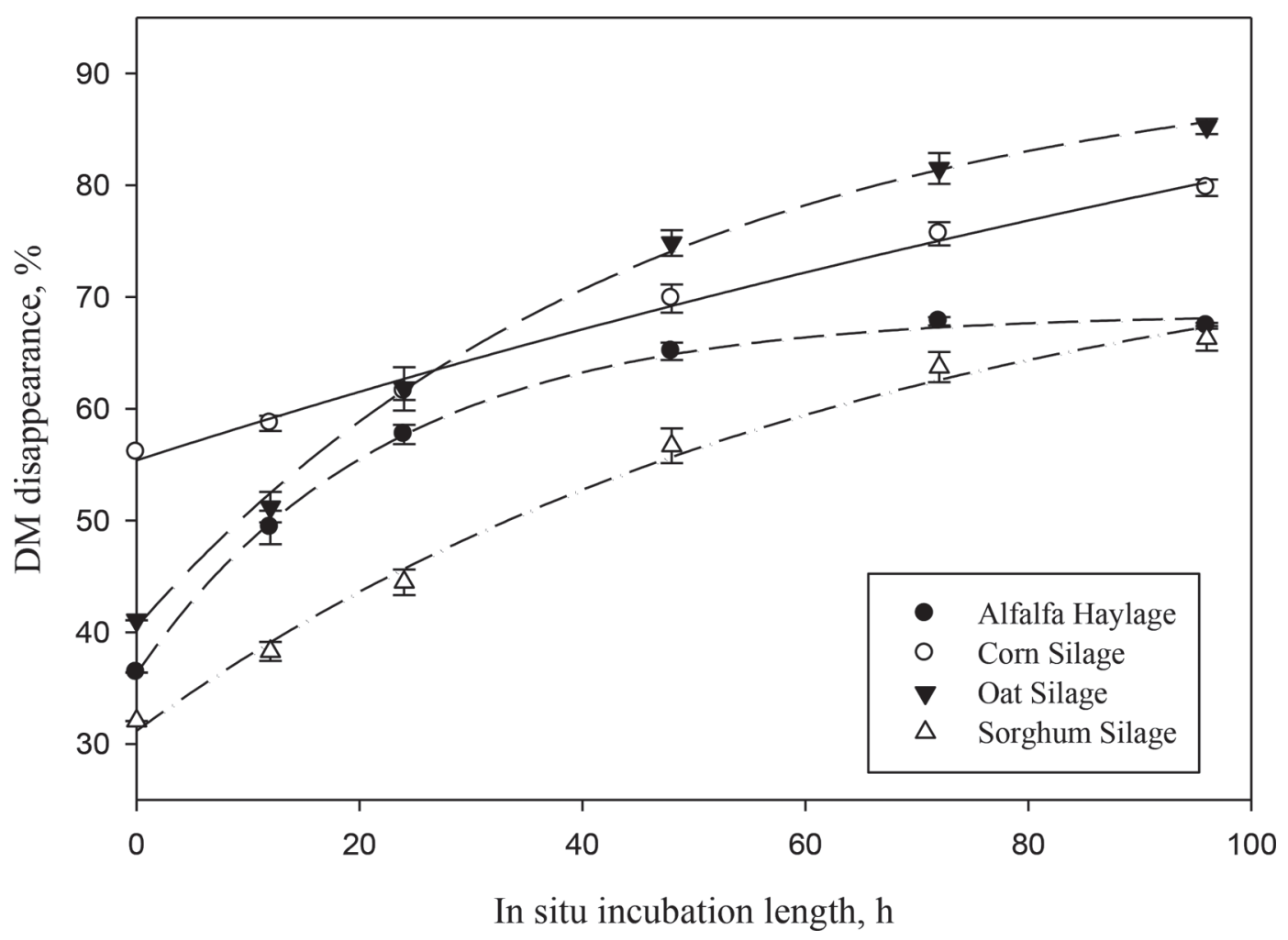

Figure 1. Ruminal in situ DM disappearance of ensiled forages. Data are means $\pm \mathrm{SE}(\mathrm{n}=6)$. Disappearance curves were fit using SigmaPlot 10.0 (Systat Software, Chicago, IL) to the equation $p=a+b\left(1-\mathrm{e}^{-c t}\right)$, where $p$ is the degraded fraction (of DM) at time $t, a$ is the soluble fraction, $b$ is the potentially degradable fraction, and $c$ is the rate of degradation of the $b$ fraction (Ørskov and McDonald, 1979).

growth, which has been shown to have $38 \%$ greater NDFD than spring-grown oats (Contreras-Govea and Albrecht, 2006). Additionally, the fall weather provided cooler growing temperatures than temperatures dur- ing a spring growing season. Forages grown at cooler temperatures deposit less lignin and have increased in vitro NDFD compared with the same forages grown at higher temperatures (Buxton, 1996).

Table 3. Ruminal in situ DM and NDF degradability of ensiled forages ${ }^{1}$

\begin{tabular}{|c|c|c|c|c|}
\hline Item & \multicolumn{4}{|c|}{ Forage } \\
\hline \multicolumn{5}{|l|}{ DM } \\
\hline Potentially degradable (fraction $b$ ). $\%$ & $32.0 \pm 1.26^{\mathrm{b}}$ & $46.0 \pm 11.80^{\mathrm{ab}}$ & $54.0 \pm 3.05^{\mathrm{a}}$ & $48.0 \pm 4.82^{\mathrm{a}}$ \\
\hline Rate of degradation of $b, \% / \mathrm{h}$ & $4.54 \pm 0.46^{\mathrm{a}}$ & $0.86 \pm 0.34^{\mathrm{c}}$ & $1.94 \pm 0.27^{\mathrm{b}}$ & $1.40 \pm 0.27^{\mathrm{bc}}$ \\
\hline Effective degradability ${ }^{2}$ & $55.7 \pm 0.48^{\mathrm{c}}$ & $64.3 \pm 0.46^{\mathrm{a}}$ & $62.2 \pm 0.47^{\mathrm{b}}$ & $47.3 \pm 0.46^{\mathrm{c}}$ \\
\hline Rate of degradation of $b, \% / \mathrm{h}$ & $2.83 \pm 0.46^{\mathrm{x}}$ & $0.57 \pm 0.02^{3}$ & $2.15 \pm 0.21^{\mathrm{xy}}$ & $1.78 \pm 0.28^{\mathrm{y}}$ \\
\hline Effective degradability $^{2}$ & $29.0 \pm 0.69^{\mathrm{b}}$ & - & $38.3 \pm 0.69^{\mathrm{a}}$ & $27.4 \pm 0.68^{\mathrm{b}}$ \\
\hline
\end{tabular}

${ }^{\mathrm{a}-\mathrm{d}}$ Means within the same row without a common superscript differ $(P<0.05)$.

${ }^{\mathrm{x}, \mathrm{y}}$ Means within the same row without a common superscript differ $(P<0.10)$.

${ }^{1}$ Values are model estimates $\pm \mathrm{SE}$ of disappearance curves fit using SigmaPlot 10.0 (Systat Software, Chicago, IL) to the equation $p=a+b(1$ $-\mathrm{e}^{-c t}$ ), where $p$ is the degraded fraction (of DM or NDF) at time $t, a$ is the soluble fraction, $b$ is the potentially degradable fraction, and $c$ is the rate of degradation of the $b$ fraction (Ørskov and McDonald, 1979); DM disappearance, $\mathrm{n}=144$; NDF disappearance, $\mathrm{n}=108$ ( $\mathrm{n}$ represents the number of observations used in the statistical analysis).

${ }^{2}$ Effective degradability (ED) was estimated as $\mathrm{ED}=a+b[c \div(c+k)]$, where $a, b$, and $p$ are as above and $k$ is the rate of passage $(\varnothing$ rskov and McDonald, 1979) assumed to be $0.03 / \mathrm{h}$ in this study.

${ }^{3}$ Corn silage NDF degradation data were fit to a linear model with an $\mathrm{R}^{2}=0.94$. 


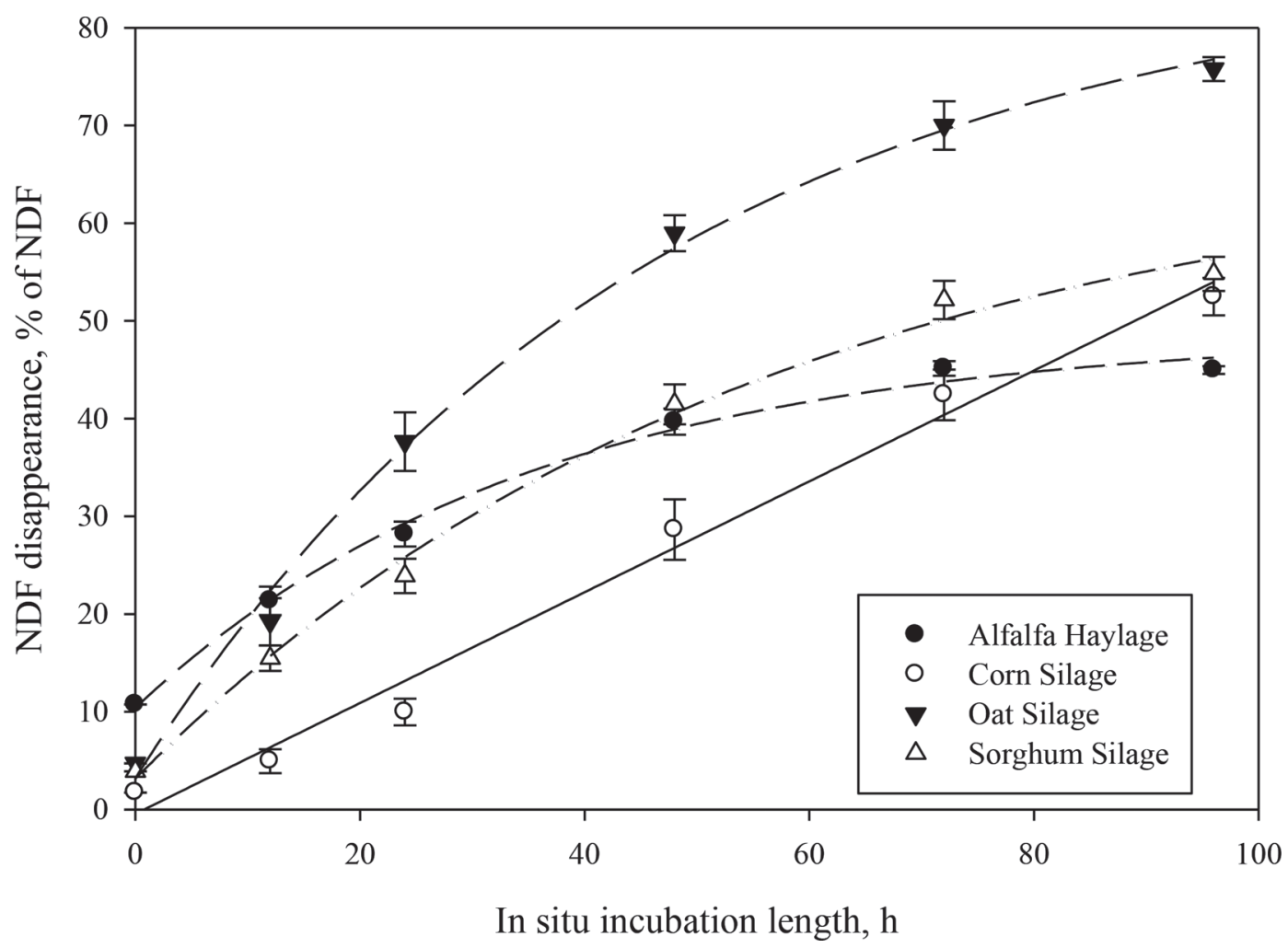

Figure 2. Ruminal in situ NDF disappearance of ensiled forages. Data are means \pm SE $(n=6)$. Disappearance curves of alfalfa haylage, sorghum silage, and oat silage were fit using SigmaPlot 10.0 (Systat Software, Chicago, IL) to the equation $p=a+b\left(1-\mathrm{e}^{-c t}\right.$ ), where $p$ is the degraded fraction (of NDF) at time $t, a$ is the soluble fraction, $b$ is the potentially degradable fraction, and $c$ is the rate of degradation of the $b$ fraction (Ørskov and McDonald, 1979). Corn silage NDF disappearance data were fit to a linear model.

Ration particle size can also affect DMI intake, but responses are not always consistent (Allen, 2000; Bhandari et al., 2008). Diets only had a slightly, but significantly $(P=0.02)$ different particle size distribution on the top, $19-\mathrm{cm}$, sieve as measured by the Penn State Particle Separator (data not shown in tables). Reported on an as-fed basis, OS had more long particles (10.6\%) than CS (7.8\%). The SS diet (9.1\%) did not differ from the other 2 diets. The other screens averaged 43.6, 17.5, and $29.7 \%$ ( $8 \mathrm{~mm}, 4 \mathrm{~mm}$, and bottom pan, respectively) of the sample. The particle distribution data are in general agreement with the recommendations of Heinrichs (2013). Forage particle buoyancy and specific gravity can affect rumen fill and DMI (Allen, 2000), but this did not appear to be the case in the current study.

Production data are presented in Table 4. Milk yield was similar for CS and OS, but decreased $(P=0.006)$ for SS. Feed efficiency was not affected by diet. Dry matter intake directly affects MY and is the likely reason for the observed MY differences in the current study. Lusk et al. (1984) reported no difference in MY in 2 experiments when BMR-12 sorghum silage completely replaced corn silage in the ration. Milk yield was lower (around $25 \mathrm{~kg} / \mathrm{d}$ ) in that study and, in contrast to the current study, a decrease in DMI was not observed. Additionally, the sorghum silage used by Lusk et al. (1984) had lignin and NDF concentrations similar to the corn silage, whereas in the current study, the sorghum silage had considerably higher lignin and NDF content than the corn silage. Aydin et al. (1999) reported decreased DMI and MY in a comparison of corn silage versus BMR sorghum diets that were 6 percentage units different in NDF. This report agrees with our finding comparing corn silage to BMR sorghum diets with a 2-percentageunit difference in NDF. In contrast, Aydin et al. (1999), in a second experiment, reported no decrease in DMI or MY in a comparison of corn silage versus BMR sorghum diets with equal NDF concentration. Grant et al. (1995) and Oliver et al. (2004) both found no difference in DMI or MY between BMR sorghum silage and corn silage diets. Their BMR sorghum silages, however, were harvested in the dough stage and contained significant amounts of starch, whereas the sorghum silage used in the current study had less than $1 \%$ starch. Miron et al. (2007) reported similar DMI and MY between diets containing BMR sorghum silage or corn silage but, unlike the current study, corn grain was added to the sorghum silage diet to increase dietary starch. Co- 
Table 4. Effect of oat and sorghum silage on DMI, milk production, and feed efficiency in lactating dairy cows

\begin{tabular}{|c|c|c|c|c|c|}
\hline \multirow[b]{2}{*}{ Item } & \multicolumn{3}{|c|}{$\operatorname{Diet}^{1}$} & \multirow[b]{2}{*}{$\mathrm{SEM}^{2}$} & \multirow{2}{*}{$\frac{P \text {-value }}{\text { Diet }}$} \\
\hline & CS & OS & SS & & \\
\hline DMI, kg/d & $26.7^{\mathrm{a}}$ & $27.1^{\mathrm{a}}$ & $26.0^{\mathrm{b}}$ & 1.69 & 0.02 \\
\hline Milk yield, kg/d & $39.6^{\mathrm{a}}$ & $40.2^{\mathrm{a}}$ & $38.7^{\mathrm{b}}$ & 3.58 & 0.006 \\
\hline Milk/DMI, $\mathrm{kg} / \mathrm{kg}$ & 1.48 & 1.49 & 1.49 & 0.05 & 0.86 \\
\hline Milk fat, $\%$ & $3.58^{\mathrm{b}}$ & $3.60^{\mathrm{b}}$ & $3.74^{\mathrm{a}}$ & 0.12 & 0.02 \\
\hline Milk fat, ${ }^{3} \mathrm{~kg} / \mathrm{d}$ & 1.42 & 1.42 & 1.39 & 0.07 & 0.78 \\
\hline Milk true protein, $\%$ & $2.85^{\mathrm{a}}$ & $2.83^{\mathrm{a}}$ & $2.77^{\mathrm{b}}$ & 0.06 & 0.03 \\
\hline Milk true protein, ${ }^{3} \mathrm{~kg} / \mathrm{d}$ & $1.13^{\mathrm{a}}$ & $1.13^{\mathrm{a}}$ & $1.04^{\mathrm{b}}$ & 0.06 & 0.05 \\
\hline Lactose, $\%$ & 5.01 & 4.98 & 4.98 & 0.05 & 0.58 \\
\hline Lactose, ${ }^{3} \mathrm{~kg} / \mathrm{d}$ & 2.00 & 2.00 & 1.88 & 0.12 & 0.17 \\
\hline MUN, mg/dL & 13.5 & 13.8 & 13.9 & 0.63 & 0.73 \\
\hline $\mathrm{ECM}^{3,4} \mathrm{~kg} / \mathrm{d}$ & 36.9 & 36.9 & 35.1 & 1.95 & 0.32 \\
\hline
\end{tabular}

a,bMeans within the same row without a common superscript differ $(P \leq 0.05)$.

${ }^{1} \mathrm{CS}=$ corn silage control diet; $\mathrm{OS}=$ oat silage diet; $\mathrm{SS}=$ sorghum silage diet.

${ }^{2}$ Largest SEM published in table; DMI, $\mathrm{n}=348$; milk yield, $\mathrm{n}=351$; milk yield $\div$ DMI, $\mathrm{n}=339$; $\mathrm{BW}, \mathrm{n}=$ 36; milk composition data, $\mathrm{n}=36$ ( $\mathrm{n}$ represents the number of observations used in the statistical analysis).

${ }^{3}$ Calculated using the milk yield of the 2 consecutive milk sampling days.

${ }^{4}$ Energy-corrected milk $(\mathrm{kg} / \mathrm{d})=\mathrm{kg}$ of milk $\times[(38.3 \times \%$ fat $\times 10+24.2 \times \%$ true protein $\times 10+16.54 \times$

$\%$ lactose $\times 10+20.7) \div 3,140]$ (Sjaunja et al., 1990).

lombini et al. (2015) replaced corn silage with sorghum sudangrass silage plus corn grain and, similar to our results, reported a tendency for a reduction in DMI along with a significant decrease in MY. They added grain to the sorghum diet to match the starch concentrations in the corn silage diet, but the sorghum was not a BMR variety. In general, differences in MY responses to sorghum silage between the current and previous studies can largely be explained by the relatively high MY in the current study and the replacement of corn silage by low starch sorghum silage without additional energy supplementation.

The OS diet had no effect on DMI or MY in the current experiment. Earlier studies reported poor results of feeding oat silage to cattle (Christensen et al., 1977; Khorasani et al., 1993; McCartney and Vaage, 1994). Oat silage harvested in the early dough stage was compared with corn silage and barley silage by Burgess et al. (1973) in dairy cows. These authors reported an increased DMI per unit of BW of the oat silage over the other treatments. However, total DMI (grain supplement plus silage) was not different in that experiment, and MY was lowest for the oat silage diet. Oltjen and Bolsen (1980) found decreased DMI in comparing oat to corn silage in an $84 \%$ silage, $16 \%$ supplement diet fed to growing steers. Both of those studies used dough stage spring-grown oats, which have more ADF than the boot stage fall-grown oats used in the current experiment. More recently, TMR containing oat silage has been shown to successfully support MY above 35 $\mathrm{kg} / \mathrm{d}$ (Leonardi et al., 2005; Bhandari et al., 2008). Milk yield of around $39 \mathrm{~kg} / \mathrm{d}$ was reported when oat silage replaced alfalfa haylage at a $25 \%$ inclusion rate in a corn silage-based diet (Leonardi et al., 2005). The oat silage in that study had similar nutrient composition to the oat silage used in the current trial. Bhandari et al. (2008), investigating the effect of silage particle length, used milk stage oat silage at $24 \%$ of the diet DM along with $24 \%$ alfalfa haylage and reported MY of $36 \mathrm{~kg} / \mathrm{d}$. Milk yield and intake data from the current study for OS agree with these more recent reports.

Compared with CS, OS did not alter milk fat concentration, but milk fat was increased $(P=0.02)$ by SS. Milk fat yield did not differ among diets. Milk true protein concentration was decreased $(P=0.03)$ by SS compared with OS or CS. Yield of milk true protein followed the same pattern. Oliver et al. (2004) did not report a change in either milk fat or protein concentration between diets based on BMR-6 sorghum and corn silage likely because of the similarly high NDF $(>38 \%$ $\mathrm{DM})$ and moderate starch $(\leq 21 \% \mathrm{DM})$ concentrations in the diets. The effect of SS on milk components is in agreement with Miron et al. (2007), who reported an increase in milk fat content and a decrease in protein content for both traditional hybrid sorghum and BMR sorghum when replacing corn silage. Their sorghum diets had higher NDF concentrations than the corn silage diet as was the case in the current study. Bernard and Tao (2015) also observed an increase in milk fat concentration of a diet based on forage sorghum silage versus corn silage, but no change occurred in milk protein. Once again, the fiber contents of the diets differed, which explained the increased milk fat content (Bernard and Tao, 2015). In that study, additional ground corn and soybean meal added to the sorghum diets may have removed differences in milk 
protein content, whereas in our experiment no additional concentrates were fed.

The increase in milk fat concentration in SS is likely multifactorial. Miron et al. (2007) suggested that body fat mobilization could help explain the high milk fat content observed in their sorghum treatments. Our milk FA data (Table 5) suggest that body fat mobilization may have played a role in the increased milk fat content of SS in the current study. We observed a decrease $(P$ $=0.03$ ) in 12:0, a de novo synthesized FA, for OS and SS and an increase $(P=0.01)$ in 18:0, a preformed FA that originates either from the diet or from lipolysis of body fat reserves (Palmquist et al., 1993). Supplemental sugar has been shown to quadratically increase milk fat concentration with optimums of 4.8 and $6.3 \%$ total sugar in the diet (Broderick and Radloff, 2004). The higher ethanol soluble carbohydrate concentration in the sorghum silage versus corn silage in the current study may have contributed to the increased milk fat, although the increase in sugar was only around $0.25 \%$ of the diet DM due to the sorghum silage, so the effect may have been small. Razzaghi et al. (2016) reported higher fat content and lower total milk trans-18:1 FA with a sucrose treatment. It is known that increases in trans-10 18:1 milk FA are positively related to milk fat depression for cows fed a low-fiber, high-oil diet (Rico and Harvatine, 2013). The SS diet had lower trans-9 18:1 and trans-10 18:1 FA $(P \leq 0.01)$, which would seem to indicate a rumen environment that was more supportive of milk fat production, but the same FA effect was observed for OS, which resulted in no change in milk fat concentration. Along with these factors, lower milk fat concentration in CS and OS may have been partially a result of the so-called dilution effect due to higher MY for these 2 treatments compared with SS. Based on this line of thought, protein should also have been concentrated, but we did not observe this effect for SS. Milk protein content is elevated by increased energy intake (Emery, 1978), and milk protein concentration may have been decreased by SS because of lower dietary digestible energy intake resulting from lower DMI with less starch and higher lignin in the sorghum silage. This situation would also explain why numerically less lactose was produced in SS. Less available energy for ruminal microbes decreases microbial protein synthesis. However, we observed only a tendency $(P=0.06)$ for decreased urinary uric acid excretion and numerically lower allantoin excretion in SS. The high digestibility of the oat silage may have provided similar amounts of energy as the corn silage to support microbial protein and milk protein synthesis. Lactose concentration and yield, MUN, and ECM yield were not affected by diet.

Several individual milk FA were affected by diet, but when they were grouped as saturated, mono-unsatu- rated, poly-unsaturated, total trans FA, or odd- and branched-chain FA, no effects were observed. Odd- and branched-chain FA are positively related to microbial flow to the duodenum (Vlaeminck et al., 2006), and no differences among diets for this parameter matches the lack of effect observed for urinary purine derivative excretion. An increase $(P<0.001)$ in iso 15:0 for OS and SS was observed, which has been positively associated with rumen acetate concentrations (Fievez et al., 2012). Milk FA $15: 0$ was decreased $(P=0.005)$ in SS indicating increased proportions of rumen butyrate and acetate and decreased propionate based on the relationships put forth by Fievez et al. (2012). These rumen VFA changes are expected with increased dietary NDF and decreased starch such as in OS and SS.

Nutrient intake and digestibility data are in Table 6. The intake data are a reflection of the differences in DMI and nutrient content of the oat, sorghum, and corn silages. Crude protein intake was greater $(P=$ 0.04) for OS compared with CS or SS. Intakes of NDF and ADF were higher $(P \leq 0.02)$ for both OS and SS versus CS. Conversely, starch intake was highest $(P<$ 0.001) for CS, intermediate for OS, and lowest for SS. Digestibility of DM, OM, CP, NDF, and ADF were all increased $(P<0.001)$ by OS compared with CS and SS. The largest increases were observed in NDF and ADF digestibilities. The SS diet resulted in lower $(P<$ 0.001) DM, OM, and CP digestibilities than the other 2 diets, but fiber digestibility was equal to that of CS. Higher lignin concentration in SS from the sorghum silage and lower lignin concentration in OS from the oat silage compared with CS can partially explain these effects because lignin concentration is negatively correlated with forage digestibility (Mertens, 1985). This explanation is supported by results from 2 experiments by Aydin et al. (1999) reporting on digestibility of BMR sorghum, traditional sorghum, and corn silage in lactating dairy cows. In the first experiment, sorghum silages had higher lignin content and decreased total-tract ADF digestibility. In the second experiment, lignin content was similar between BMR sorghum and corn silage, and the 2 forages had similar in vitro potentially digestible NDF and 30-h NDFD.

Fiber digestion is known to be negatively affected by higher starch concentrations causing a reduction in rumen pH (Firkins, 1997; Lechartier and Peyraud, 2011). In the current study, both OS and SS had lower starch concentrations compared with CS. This situation may have promoted fiber degradation in the rumen because the decrease in NFC (2.5 to 2.8 percentage units) was in the range reported to have a large digestibility response (Sarwar et al., 1992). Increased fiber digestion from lower dietary starch concentration and lower DMI with slower passage rate in SS may have been counter- 
Table 5. Effect of oat and sorghum silage on milk fatty acid composition (g/100 g of total fatty acids) in lactating dairy cows

\begin{tabular}{|c|c|c|c|c|c|}
\hline \multirow[b]{2}{*}{ Fatty acid } & \multicolumn{3}{|c|}{$\operatorname{Diet}^{1}$} & \multirow[b]{2}{*}{$\mathrm{SEM}^{2}$} & \multirow{2}{*}{$\frac{P \text {-value }}{\text { Diet }}$} \\
\hline & CS & OS & SS & & \\
\hline $4: 0$ & 2.59 & 2.58 & 2.74 & 0.088 & 0.22 \\
\hline $6: 0$ & 2.12 & 2.14 & 2.12 & 0.041 & 0.88 \\
\hline $8: 0$ & 1.25 & 1.25 & 1.24 & 0.023 & 0.76 \\
\hline 10:0 & 2.99 & 2.93 & 2.85 & 0.072 & 0.11 \\
\hline $10: 1$ & 0.25 & 0.24 & 0.24 & 0.012 & 0.22 \\
\hline 11:0 & $0.05^{\mathrm{a}}$ & $0.05^{\mathrm{a}}$ & $0.04^{\mathrm{b}}$ & 0.004 & $<0.001$ \\
\hline $12: 0$ & $3.41^{\mathrm{a}}$ & $3.29^{\mathrm{ab}}$ & $3.20^{\mathrm{b}}$ & 0.087 & 0.03 \\
\hline 13:0 iso & 0.03 & 0.03 & 0.03 & 0.001 & 0.07 \\
\hline 13:0 anteiso & $0.06^{\mathrm{a}}$ & $0.06^{\mathrm{b}}$ & $0.05^{\mathrm{b}}$ & 0.003 & 0.04 \\
\hline $13: 0$ & $0.10^{\mathrm{a}}$ & $0.10^{\mathrm{a}}$ & $0.09^{\mathrm{b}}$ & 0.004 & 0.001 \\
\hline 14:0 iso & 0.11 & 0.11 & 0.11 & 0.011 & 0.88 \\
\hline $14: 0$ & 11.0 & 10.8 & 10.6 & 0.171 & 0.16 \\
\hline $14: 1$ & $0.72^{\mathrm{a}}$ & $0.66^{\mathrm{b}}$ & $0.66^{\mathrm{b}}$ & 0.044 & 0.03 \\
\hline 15:0 iso & $0.20^{\mathrm{b}}$ & $0.22^{\mathrm{a}}$ & $0.22^{\mathrm{a}}$ & 0.006 & $<0.001$ \\
\hline 15:0 anteiso & 0.41 & 0.40 & 0.40 & 0.009 & 0.90 \\
\hline $15: 0$ & $0.94^{\mathrm{a}}$ & $0.93^{\mathrm{a}}$ & $0.88^{\mathrm{b}}$ & 0.026 & 0.005 \\
\hline 16:0 iso & 0.23 & 0.24 & 0.24 & 0.021 & 0.42 \\
\hline 16:0 & 26.6 & 25.7 & 25.8 & 0.418 & 0.07 \\
\hline $16: 1$ & 0.92 & 0.85 & 0.89 & 0.046 & 0.12 \\
\hline 17:0 iso & 0.28 & 0.29 & 0.29 & 0.011 & 0.09 \\
\hline 17:0 anteiso & 0.38 & 0.38 & 0.38 & 0.007 & 0.41 \\
\hline $17: 0$ & 0.49 & 0.50 & 0.52 & 0.008 & 0.06 \\
\hline $17: 1$ & 0.14 & 0.14 & 0.15 & 0.007 & 0.31 \\
\hline $18: 0$ & $13.3^{\mathrm{b}}$ & $14.2^{\mathrm{a}}$ & $14.6^{\mathrm{a}}$ & 0.450 & 0.01 \\
\hline trans-4 18:1 & 0.03 & 0.02 & 0.03 & 0.001 & 0.19 \\
\hline trans-5 18:1 & 0.02 & 0.02 & 0.02 & 0.001 & 0.29 \\
\hline trans- 6,8 18:1 & 0.33 & 0.32 & 0.32 & 0.010 & 0.54 \\
\hline trans-9 18:1 & $0.26^{\mathrm{a}}$ & $0.25^{\mathrm{b}}$ & $0.25^{\mathrm{b}}$ & 0.007 & 0.01 \\
\hline trans-10 18:1 & $0.49^{\mathrm{a}}$ & $0.45^{\mathrm{b}}$ & $0.45^{\mathrm{b}}$ & 0.019 & $<0.001$ \\
\hline trans-11 18:1 & 1.21 & 1.24 & 1.24 & 0.042 & 0.68 \\
\hline trans-12 18:1 & 0.50 & 0.46 & 0.48 & 0.032 & 0.52 \\
\hline cis-9 18:1 & 18.9 & 19.3 & 19.5 & 0.480 & 0.28 \\
\hline trans-15 18:1 & 0.38 & 0.38 & 0.37 & 0.015 & 0.35 \\
\hline cis-11 18:1 & 0.70 & 0.66 & 0.67 & 0.028 & 0.50 \\
\hline cis-12 18:1 & $0.51^{\mathrm{a}}$ & $0.49^{\mathrm{b}}$ & $0.47^{\mathrm{c}}$ & 0.020 & $<0.001$ \\
\hline Linoleic acid & 3.70 & 3.66 & 3.57 & 0.072 & 0.36 \\
\hline$\alpha$-Linolenic acid & $0.62^{\mathrm{b}}$ & $0.67^{\mathrm{a}}$ & $0.63^{\mathrm{b}}$ & 0.014 & 0.005 \\
\hline $20: 0$ & $0.16^{\mathrm{b}}$ & $0.17^{\mathrm{a}}$ & $0.17^{\mathrm{a}}$ & 0.005 & 0.005 \\
\hline $20: 1$ & 0.04 & 0.04 & 0.04 & 0.002 & 0.13 \\
\hline cis-9,trans-11 CLA & 0.52 & 0.51 & 0.51 & 0.028 & 0.69 \\
\hline $20: 2$ & 0.04 & 0.04 & 0.03 & 0.004 & 0.41 \\
\hline $20: 3$ & 0.15 & 0.14 & 0.15 & 0.010 & 0.80 \\
\hline $20: 4$ & 0.17 & 0.16 & 0.16 & 0.010 & 0.05 \\
\hline $20: 5$ & 0.04 & 0.04 & 0.04 & 0.002 & 0.68 \\
\hline $22: 0$ & $0.06^{\mathrm{b}}$ & $0.06^{\mathrm{a}}$ & $0.06^{\mathrm{a}}$ & 0.002 & $<0.001$ \\
\hline $24: 0$ & $0.03^{\mathrm{b}}$ & $0.03^{\mathrm{a}}$ & $0.03^{\mathrm{a}}$ & 0.002 & 0.001 \\
\hline $24: 1$ & $<0.01$ & $<0.01$ & $<0.01$ & $<0.001$ & 0.39 \\
\hline $22: 4$ & 0.03 & 0.03 & 0.03 & 0.004 & 0.18 \\
\hline $22: 5$ & 0.07 & 0.07 & 0.07 & 0.005 & 0.86 \\
\hline$\Sigma$ SFA & 66.7 & 66.5 & 66.6 & 0.641 & 0.86 \\
\hline$\Sigma$ MUFA & 25.4 & 25.5 & 25.8 & 0.566 & 0.67 \\
\hline$\Sigma$ PUFA & 5.35 & 5.33 & 5.18 & 0.093 & 0.32 \\
\hline$\Sigma$ trans $\mathrm{FA}$ & 3.21 & 3.16 & 3.17 & 0.100 & 0.62 \\
\hline$\Sigma$ OBCFA $^{3}$ & 3.36 & 3.39 & 3.37 & 0.056 & 0.76 \\
\hline Unknown & 2.52 & 2.64 & 2.46 & 0.080 & 0.16 \\
\hline
\end{tabular}

${ }^{\mathrm{a}-\mathrm{c}}$ Means within the same row without a common superscript differ $(P<0.05)$.

${ }^{1} \mathrm{CS}=$ corn silage control diet; $\mathrm{OS}=$ oat silage diet; $\mathrm{SS}=$ sorghum silage diet.

${ }^{2}$ Largest SEM shown; $\mathrm{n}=36$ for all variables ( $\mathrm{n}$ represents number of observations used in the statistical analysis). Data are presented as LSM.

${ }^{3}$ Sum of odd- and branched-chain fatty acids (iso13:0, anteiso13:0, 13:0, iso14:0, iso15:0, anteiso15:0, 15:0, iso16:0, iso17:0, 17:0, 17:1). 
Table 6. Effect of oat and sorghum silage on nutrient intake and apparent total-tract digestibility in lactating dairy cows

\begin{tabular}{|c|c|c|c|c|c|}
\hline \multirow[b]{2}{*}{ Item } & \multicolumn{3}{|c|}{$\operatorname{Diet}^{1}$} & \multirow[b]{2}{*}{$\mathrm{SEM}^{2}$} & \multirow{2}{*}{$\frac{P \text {-value }}{\text { Diet }}$} \\
\hline & CS & OS & SS & & \\
\hline \multicolumn{6}{|l|}{ Intake, $\mathrm{kg} / \mathrm{d}$} \\
\hline $\mathrm{DM}^{3}$ & 26.1 & 26.9 & 25.9 & 1.15 & 0.23 \\
\hline OM & 24.3 & 24.9 & 24.1 & 1.06 & 0.37 \\
\hline $\mathrm{CP}$ & $4.25^{\mathrm{b}}$ & $4.52^{\mathrm{a}}$ & $4.30^{\mathrm{b}}$ & 0.19 & 0.04 \\
\hline Starch & $6.22^{\mathrm{a}}$ & $5.45^{\mathrm{b}}$ & $5.06^{\mathrm{c}}$ & 0.24 & $<0.001$ \\
\hline NDF & $8.34^{\mathrm{b}}$ & $9.00^{\mathrm{a}}$ & $8.87^{\mathrm{a}}$ & 0.38 & 0.02 \\
\hline NDF, $\%$ of BW & 1.43 & 1.51 & 1.50 & 0.05 & 0.17 \\
\hline Forage NDF, $\%$ of $\mathrm{BW}$ & $0.99^{\mathrm{b}}$ & $1.08^{\mathrm{a}}$ & $1.08^{\mathrm{a}}$ & 0.04 & $<0.01$ \\
\hline $\mathrm{ADF}$ & $5.79^{\mathrm{b}}$ & $6.28^{\mathrm{a}}$ & $6.15^{\mathrm{a}}$ & 0.27 & 0.01 \\
\hline \multicolumn{6}{|l|}{ Apparent digestibility, \% } \\
\hline DM & $68.1^{\mathrm{b}}$ & $69.8^{\mathrm{a}}$ & $66.2^{\mathrm{c}}$ & 0.29 & $<0.001$ \\
\hline $\mathrm{OM}$ & $69.1^{\mathrm{b}}$ & $70.8^{\mathrm{a}}$ & $67.3^{\mathrm{c}}$ & 0.28 & $<0.001$ \\
\hline $\mathrm{CP}$ & $66.0^{\mathrm{b}}$ & $67.6^{\mathrm{a}}$ & $64.6^{\mathrm{c}}$ & 0.52 & $<0.001$ \\
\hline Starch & $98.3^{\mathrm{a}}$ & $98.0^{\mathrm{b}}$ & $97.7^{\mathrm{c}}$ & 0.08 & $<0.001$ \\
\hline NDF & $43.8^{\mathrm{b}}$ & $50.8^{\mathrm{a}}$ & $44.8^{\mathrm{b}}$ & 0.56 & $<0.001$ \\
\hline $\mathrm{ADF}$ & $41.6^{\mathrm{b}}$ & $49.6^{\mathrm{a}}$ & $42.1^{\mathrm{b}}$ & 0.64 & $<0.001$ \\
\hline
\end{tabular}

${ }^{\mathrm{a}-\mathrm{c}}$ Means within the same row without a common superscript differ $(P<0.05)$.

${ }^{1} \mathrm{CS}=$ corn silage control diet; $\mathrm{OS}=$ oat silage diet; $\mathrm{SS}=$ sorghum silage diet.

${ }^{2}$ Largest SEM published in table; $\mathrm{n}=36$ ( $\mathrm{n}$ represents the number of observations used in the statistical analysis).

${ }^{3} \mathrm{DM}$ intake reported is during the collection period for digestibility.

balanced by decreased DM digestibility due to higher lignin content from the sorghum silage. For the OS diet, lower starch and lower lignin concentrations supported higher fiber digestion. Starch is more digestible than $\mathrm{NDF}$, which may explain the decrease in DM and OM apparent digestibility for the SS diet, but does not explain the increase in DM and OM apparent digestibility for the OS diet. It should be noted that total-tract apparent digestibility was estimated using iNDF as an internal marker. Although significant, DM, OM, and $\mathrm{CP}$ apparent digestibilities are less than 2 percentage units different from CS and reflect differences in the TMR iNDF (iNDF, \% \pm SD: CS, $12.0 \pm 0.45$; OS $11.2 \pm 0.37$; SS $12.8 \pm 0.54$ ). The higher CP apparent digestibility in the OS diet could have resulted from increased protein solubility (and perhaps ammonia concentration, which was not analyzed in this study) in the oat silage. The CS diet had the highest $(P<$ $0.001)$ starch digestibility followed by OS and SS. The starch in the corn silage may have been more digestible than starch in the ground corn, which was the other major starch source in the diets. Indeed, Lanzas et al. (2007) reported a higher ruminal starch degradation rate for processed corn silage $(0.32 / \mathrm{h})$ compared with finely ground corn $(0.15 / \mathrm{h})$. The CS diet in the current experiment contained proportionally more starch from corn silage than OS or SS.

Nitrogen utilization data are in Table 7 . The OS diet resulted in higher $(P=0.04)$ intake of $\mathrm{N}$ than either SS or CS because of the higher CP content of the oat silage. A tendency for higher $(P=0.08)$ total excreta $\mathrm{N}$ for OS compared with CS was observed, which reflects the higher $\mathrm{N}$ intake and similar milk $\mathrm{N}$ secretion. Compared with CS, OS increased $(P=0.03)$ urinary urea $\mathrm{N}$ excretion. The higher $\mathrm{N}$ intake and higher soluble protein in the oat silage was the likely reason for increased urinary urea $\mathrm{N}$ excretion with OS compared with the other diets (Van Soest, 1994; Broderick, 2003). The sorghum silage had a higher CP content than corn silage, but, with the decrease in DMI, N intake for SS was not different from that for CS. A tendency $(P=$ 0.07 ) was observed for increased urinary urea $\mathrm{N}$ in SS versus CS, which may be explained with lower energy availability in the rumen with the former diet. Milk N secretion and use efficiency were decreased $(P=0.05)$ by SS compared with CS due to the decreased milk and milk protein yields with SS discussed earlier. As a percentage of intake, urine $\mathrm{N}$ and total excreta $\mathrm{N}$ were unaffected by diet; however, fecal $\mathrm{N}$ excretion was highest $(P<0.001)$ for SS, intermediate for CS, and lowest for OS. This finding agrees with the lower and higher total-tract apparent CP digestibility of these diets, respectively.

Enteric emissions of $\mathrm{CO}_{2}$ and $\mathrm{CH}_{4}$ (Table 7) were not different among diets. Methane emissions were not affected when presented as yield (i.e., per $\mathrm{kg}$ of DMI) or intensity (i.e., per $\mathrm{kg}$ of MY). Hristov et al. (2013) has suggested that increasing forage digestibility is expected to decrease enteric $\mathrm{CH}_{4}$ emission intensity and is a promising mitigation strategy. Hart et al. (2009) 
Table 7. Effect of oat and sorghum silage on nitrogen utilization, urinary purine derivative excretion, and carbon dioxide $\left(\mathrm{CO}_{2}\right)$ and methane $\left(\mathrm{CH}_{4}\right)$ emissions ${ }^{1}$ in lactating dairy cows

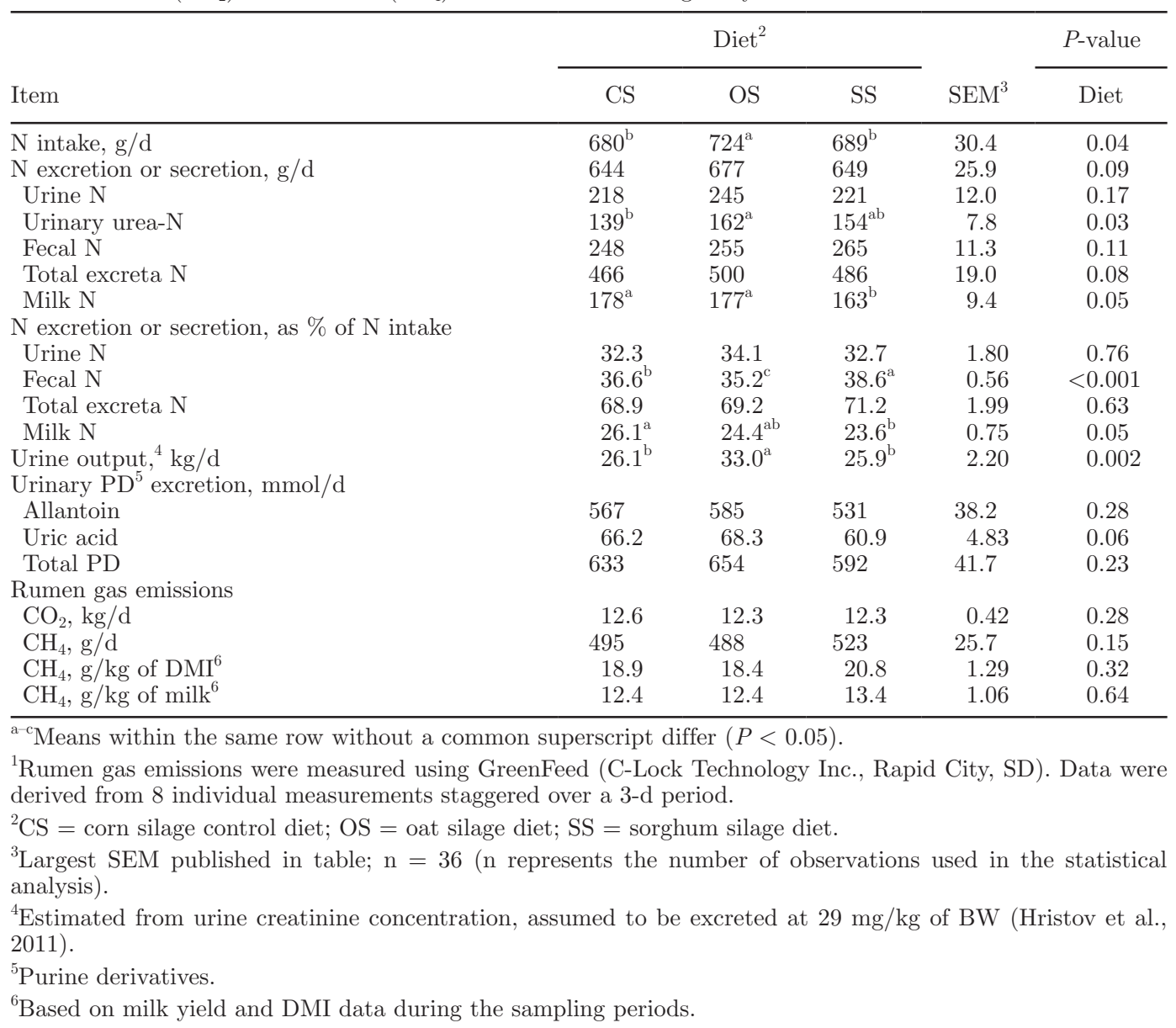

fed low and high digestible grass to cows and measured $\mathrm{CH}_{4}$ emissions. They reported higher $\mathrm{CH}_{4}$ emissions in cows fed higher digestible grass, but emission intensity was lower. We did not observe an effect on $\mathrm{CO}_{2}$ or $\mathrm{CH}_{4}$ emissions by diet despite the differences in apparent digestibility. The likely explanation for this lack of effect is the small magnitude of differences in $\mathrm{OM}$ digestibility, DMI, and MY. Dry matter intake is the greatest driver of enteric $\mathrm{CH}_{4}$ emission in ruminants and only differed by $5 \%$ among diets in this study. Colombini et al. (2015) similarly reported only tendencies of higher $\mathrm{CH}_{4}$ emissions when feeding sorghum silage in place of corn silage to lactating dairy cows. In their study, DMI differed by $9 \%$. Higher DMI in the current study explains why daily $\mathrm{CH}_{4}$ emissions results were higher than those reported by Colombini et al. (2015; 523 versus $342 \mathrm{~g} / \mathrm{d}$, respectively), yet emission intensity was lower, likely due to higher MY in the current experiment.

The economic outcome of the use of alternative forages is critical for their adoption. The IOFC of CS and OS were comparable at $\$ 9.49$ and $\$ 9.43 /$ cow per day, respectively (data not in tables). The SS diet resulted in slightly lower IOFC, $\$ 9.32 / \mathrm{cow} / \mathrm{d}$. A disadvantage in double cropping fall oats in central Pennsylvania is that they must be planted in mid-August to yield well. To plant at that time, a short-season corn $(<85 \mathrm{~d}$ relative maturity) must be used. Short-season corn usually has a decreased yield compared with longer season varieties, and its use raises corn crop production costs. The SS diet had the lowest IOFC due to a lower MY and a lower BMR sorghum crop yield, even though input costs were lower. When we ran the IOFC analysis with a 65 milking cow dairy, we had to account for rental costs of additional arable land to produce the necessary forage because of the low yield from a late planting date. Sorghum would have an advantage of using less irrigation water, but irrigation is not very common in the northeastern United States, and therefore it was not included in the IOFC analysis. Sorghum can perform better than corn silage on soils with low water-holding capacity, which would positively affect the IOFC of SS. Using a scenario of a higher yield of $13.4 \mathrm{t} / \mathrm{ha}$ that would be more typical with a proper planting, we found 
the IOFC of SS to increase to $\$ 9.43 /$ cow per day. This outcome is equal to that of the OS scenario and only $\$ 0.06 /$ cow per day lower than the CS scenario. The reported results are only a model and individual farm results would vary, but they do demonstrate that, financially, these forages deserve consideration in dairy farm crop rotations and lactating cow feeding programs.

\section{CONCLUSIONS}

In this study, we demonstrated that fall-grown oat and BMR-6 dwarf sorghum silages could support MY above $38 \mathrm{~kg} / \mathrm{d}$ when included at $10 \%$ of the diet DM replacing corn silage. The OS diet gave similar DMI, milk, and milk component yields as the control corn silage diet. The higher milk and urinary urea $\mathrm{N}$ excretion with OS reveals a potential for reducing dietary RDP from other feed sources when replacing corn silage for oat silage. The SS diet decreased DMI, milk, and milk protein yields, which indicates a need for additional rumen digestible energy sources when feeding low-starch sorghum silage in place of corn silage. Production data from this experiment provide useful information, but they should be interpreted with caution because of the lower number of experimental units. The alternative forages tested in this study have potential in an integrated cropping strategy and nutritional program for high-producing dairy cows.

\section{ACKNOWLEDGMENTS}

This project was supported by the Northeast Sustainable Agriculture Research and Education (SARE) program; SARE is a program of the National Institute of Food and Agriculture, US Department of Agriculture (Washington, DC). The authors thank the staff of Farm Operations and Services of the Pennsylvania State University for growing and harvesting the crops fed in our experiment. We also thank the staff of the Pennsylvania State University's Dairy Teaching and Research Center for their conscientious care of the experimental cows. Additionally, we thank Virginia Ishler for her help with the IOFC analysis.

\section{REFERENCES}

Abdelhadia, L. O., and F. J. Santini. 2006. Corn silage versus grain sorghum silage as a supplement to growing steers grazing high quality pastures: Effects on performance and ruminal fermentation. Anim. Feed Sci. Technol. 127:33-43.

Allen, M. S. 2000. Effects of diet on short-term regulation of feed intake by lactating dairy cattle. J. Dairy Sci. 83:1598-1624.

AOAC International. 2000. Official Methods of Analysis. 17th ed. AOAC International, Arlington, VA.

AOAC International. 2006. Official Methods of Analysis. 18th ed. AOAC International, Arlington, VA.
Aydin, G., R. J. Grant, and J. O'Rear. 1999. Brown midrib sorghum in diets for lactating dairy cows. J. Dairy Sci. 82:2127-2135.

Bernard, J. K., and S. Tao. 2015. Short communication: Production response of lactating dairy cows to brachytic forage sorghum silage compared with corn silage from first or second harvest. J. Dairy Sci. 98:8994-9000.

Bhandari, S. K., S. Li, K. H. Ominski, K. M. Wittenberg, and J. C. Plaizier. 2008. Effects of the chop lengths of alfalfa silage and oat silage on feed intake, milk production, feeding behavior, and rumen fermentation of dairy cows. J. Dairy Sci. 91:1942-1958.

Boivin, M., R. Gervais, and P. Y. Chouinard. 2013. Effect of grain and forage fractions of corn silage on milk production and composition in dairy cows. Animal 7:245-254.

Branson, T. F., P. L. Guss, and E. E. Ortman. 1969. Toxicity of sorghum roots to larvae of the western corn rootworm. J. Econ. Entomol. $62: 1375-1378$

Broderick, G. A. 2003. Effects of varying dietary protein and energy levels on the production of lactating dairy cows. J. Dairy Sci $86: 1370-1381$

Broderick, G. A., and W. J. Radloff. 2004. Effect of molasses supplementation on the production of lactating dairy cows fed diets based on alfalfa and corn silage. J. Dairy Sci. 87:2997-3009.

Burgess, P. L., J. W. G. Nicholson, and E. A. Grant. 1973. Yield and nutritive value of corn, barley, wheat, and forage oats as silage for lactating dairy cows. Can. J. Anim. Sci. 53:245-250.

Buxton, D. R. 1996. Quality-related characteristics of forages as influenced by plant environment and agronomic factors. Anim. Feed Sci. Technol. 59:37-49.

Carey, P. L., K. C. Cameron, H. J. Di, G. R. Edwards, and D. F. Chapman. 2016. Sowing a winter catch crop can reduce nitrate leaching losses from winter-applied urine under simulated forage grazing: A lysimeter study. Soil Use Manage. 32:329-337.

Chen, X. B., Y. K. Chen, M. F. Franklin, E. R. Ørskov, and W. J. Shand. 1992. The effect of feed intake and body weight on purine derivative excretion and microbial protein supply in sheep. J. Anim. Sci. 70:1534-1542.

Christensen, D. A., B. D. Owen, G. Steacy, J. P. Mtimuni, and W. L. Crowlen. 1977. Nutritive value of whole crop silage made from seven cereal cultivars. Can. J. Anim. Sci. 57:537-542.

Colombini, S., M. Zucali, L. Rapetti, G. M. Crovetto, A. Sandrucci, and L. Bava. 2015. Substitution of corn silage with sorghum silages in lactating cow diets: In vivo methane emission and global warming potential of milk production. Agric. Syst. 136:106-113.

Contreras-Govea, F. E., and K. A. Albrecht. 2006. Forage production and nutritive value of oat in autumn and early summer. Crop Sci. 46:2382-2386

Di, H. J., and K. C. Cameron. 2002. Nitrate leaching in temperate agroecosystems: Sources, factors and mitigating strategies. Nutr. Cycl. Agroecosyst. 64:237-256.

DuBois, M., K. A. Gilles, J. K. Hamilton, P. A. Rebers, and F. Smith 1956. Colorimetric method for determination of sugars and related substances. Anal. Chem. 28:350-356.

Emery, R. S. 1978. Feeding for increased milk protein content. J. Dairy Sci. $61: 825-828$.

Faé, G. S., R. M. Sulc, D. J. Barker, R. P. Dick, M. L. Eastridge, and N. Lorenz. 2009. Integrating winter annual forages into a no-till corn silage system. Agron. J. 101:1286-1296.

Fievez, V., E. Colman, J. M. Castro-Montoya, I. Stefanov, and B. Vlaeminck. 2012. Milk odd- and branched-chain fatty acids as biomarkers of rumen function-An update. Anim. Feed Sci. Technol. 172:51-65

Firkins, J. L. 1997. Effects of feeding nonforage fiber sources on site of fiber digestion. J. Dairy Sci. 80:1426-1437.

Gentry, L. F., M. L. Ruffo, and F. E. Below. 2013. Identifying factors controlling the continuous corn yield penalty. Agron. J. 105:295303.

Goering, H. K., and P. J. Van Soest. 1970. Forage Fiber Analysis. USDA Agricultural Research Service. Handbook number 379. U.S. Dept. of Agriculture. Superintendent of Documents, US Government Printing Office, Washington, DC. 
Grant, R. J., S. G. Haddad, K. J. Moore, and J. F. Pedersen. 1995. Brown midrib sorghum silage for midlactation dairy cows. J. Dairy Sci. 78:1970-1980.

Hall, M. B. 2009. Determination of starch, including maltooligosaccharides, in animal feeds: Comparison of methods and a method recommended for AOAC collaborative study. J. AOAC Int. 92:42-49.

Harper, M. T., J. Oh, F. Giallongo, G. W. Roth, and A. N. Hristov. 2017. Inclusion of wheat and triticale silage in the diet of lactating dairy cows. J. Dairy Sci. 100. https://doi.org/10.3168/jds.201712553.

Hart, K. J., P. G. Martin, P. A. Foley, D. A. Kenny, and T. M. Boland. 2009. Effect of sward dry matter digestibility on methane production, ruminal fermentation, and microbial populations of zero-grazed beef cattle. J. Anim. Sci. 87:3342-3350.

Heinrichs, A. J. 2013. The Penn State Particle Separator. DSE 13-186. Penn State Coop. Ext., University Park, PA.

Hristov, A. N., C. Lee, T. Cassidy, M. Long, K. Heyler, B. Corl, and R. Forster. 2011. Effects of lauric and myristic acids on ruminal fermentation, production, and milk fatty acid composition in lactating dairy cows. J. Dairy Sci. 94:382-395.

Hristov, A. N., J. Oh, J. L. Firkins, J. Dijkstra, E. Kebreab, G. Waghorn, H. P. S. Makkar, A. T. Adesogan, W. Yang, C. Lee, P. J. Gerber, B. Henderson, and J. M. Tricarico. 2013. Special topicsMitigation of methane and nitrous oxide emissions from animal operations: I. A review of enteric methane mitigation options. J. Anim. Sci. 91:5045-5069.

Hristov, A. N., J. Oh, F. Giallongo, T. Frederick, H. Weeks, P. R. Zimmerman, R. A. Hristova, S. R. Zimmerman, and A. F. Branco. 2015. The use of an automated system (GreenFeed) to monitor enteric methane and carbon dioxide emissions from ruminant animals. J. Vis. Exp. 103:e52904.

Huhtanen, P., K. Kaustell, and S. Jaakkola. 1994. The use of internal markers to predict total digestibility and duodenal flow of nutrients in cattle given six different diets. Anim. Feed Sci. Technol. 48:211-227.

Khorasani, G. R., E. K. Okine, J. J. Kennelly, and J. H. Helm. 1993. Effect of whole crop cereal grain silage substituted for alfalfa silage on performance of lactating dairy cows. J. Dairy Sci. 76:3536-3546.

Krishnamoorthy, U., T. V. Muscato, C. J. Sniffen, and P. J. Van Soest. 1982. Nitrogen fractions in selected feedstuffs. J. Dairy Sci. $65: 217-225$

Lanzas, C., C. J. Sniffen, S. Seo, L. O. Tedeschi, and D. G. Fox. 2007. A revised CNCPS feed carbohydrate fractionation scheme for formulating rations for ruminants. Anim. Feed Sci. Technol. 136:167-190.

Lechartier, C., and J. L. Peyraud. 2011. The effects of starch and rapidly degradable dry matter from concentrate on ruminal digestion in dairy cows fed corn silage-based diets with fixed forage proportion. J. Dairy Sci. 94:2440-2454.

Lee, C., A. N. Hristov, T. W. Cassidy, K. S. Heyler, H. Lapierre, G. A. Varga, M. J. de Veth, R. A. Patton, and C. Parys. 2012. Rumenprotected lysine, methionine, and histidine increase milk protein yield in dairy cows fed a metabolizable protein-deficient diet. J. Dairy Sci. 95:6042-6056.

Leonardi, C., K. J. Shinners, and L. E. Armentano. 2005. Effect of different dietary geometric mean particle length and particle size distribution of oat silage on feeding behavior and productive performance of dairy cattle. J. Dairy Sci. 88:698-710.

Lusk, J. W., P. K. Karau, D. O. Balogu, and L. M. Gourley. 1984. Brown midrib sorghum or corn silage for milk production. J. Dairy Sci. 67:1739-1744.

McCartney, D., and A. Vaage. 1994. Comparative yield and feeding value of barley, oat and triticale silage. Can. J. Anim. Sci. 74:9196.

Mertens, D. R. 1985. Effect of fiber on feed quality for dairy cows. Pages 209-224 in 46th Minnesota Nutrition Conference Proc. University of Minnesota, Saint Paul.

Mertens, D. R. 2009. Maximizing forage use by dairy cows. Pages $303-$ 319 in Proc. 27th Annual Western Canadian Dairy Seminar, Red Deer, Alberta. University of Alberta, Edmonton, Alberta, Canada.
Miron, J., E. Zuckerman, G. Adin, R. Solomon, E. Shoshani, M. Nikbachat, E. Yosef, A. Zenou, Z. G. Weinberg, Y. Chen, I. Halachmi, and D. Ben-Ghedalia. 2007. Comparison of two forage sorghum varieties with corn and the effect of feeding their silages on eating behavior and lactation performance of dairy cows. Anim. Feed Sci. Technol. 139:23-39.

Nichols, S. W., M. A. Froetschel, H. E. Amos, and L. O. Ely. 1998. Effects of fiber from tropical corn and forage sorghum silages on intake, digestion, and performance of lactating dairy cows. J. Dairy Sci. 81:2383-2393.

NRC. 2001. Nutrient Requirements of Dairy Cattle. 7th rev. ed. Natl. Acad. Press, Washington, DC.

Oliver, A. L., R. J. Grant, J. F. Pedersen, and J. O'Rear. 2004. Comparison of brown midrib- 6 and -18 forage sorghum with conventional sorghum and corn silage in diets of lactating dairy cows. J. Dairy Sci. 87:637-644.

Oltjen, J. W., and K. K. Bolsen. 1980. Wheat, barley, oat and corn silages for growing steers. J. Anim. Sci. 51:958-965.

Ørskov, E. R., and I. McDonald. 1979. The estimation of protein degradability in the rumen from incubation measurements weighted according to rate of passage. J. Agric. Sci. (Camb.) 92:499-503.

Palmquist, D. L., A. D. Beaulieu, and D. M. Barbano. 1993. Feed and animal factors influencing milk fat composition. J. Dairy Sci. $76: 1753-1771$

Penn State Extension. 2015. Income over feed cost. Accessed Oct. 10, 2016. http://extension.psu.edu/animals/dairy/businessmanagement/financial-tools/income-over-feed-cost.

Penn State Extension. 2016. Cash flow spreadsheet. Accessed Oct. 10, 2016. http://extension.psu.edu/animals/dairy/businessmanagement/financial-tools/cash-flow-planning.

Razzaghi, A., R. Valizadeh, A. A. Naserian, M. Danesh Mesgaran, A. J. Carpenter, and M. H. Ghaffari. 2016. Effect of dietary sugar concentration and sunflower seed supplementation on lactation performance, ruminal fermentation, milk fatty acid profile, and blood metabolites of dairy cows. J. Dairy Sci. 99:3539-3548.

Rico, D. E., and K. J. Harvatine. 2013. Induction of and recovery from milk fat depression occurs progressively in dairy cows switched between diets that differ in fiber and oil concentration. J. Dairy Sci. 96:6621-6630.

Sarwar, M., J. L. Firkins, and M. L. Eastridge. 1992. Effects of varying forage and concentrate carbohydrates on nutrient digestibilities and milk production by dairy cows. J. Dairy Sci. 75:1533-1542.

Shepherd, M. A. 1999. The effectiveness of cover crops during eight years of a UK sandland rotation. Soil Use Manage. 15:41-48.

Sindelar, A. J., M. R. Schmer, V. L. Jin, B. J. Wienhold, and G. E. Varvel. 2016. Crop rotation affect corn, grain sorghum, and soybean yields and nitrogen recovery. Agron. J. 108:1592-1602.

Sjaunja, L. O., L. Baevre, L. Junkkarinen, J. Pedersen, and J. Setälä. 1990. A Nordic proposal for an energy corrected milk (ECM) formula. Proc. 27th Session Int. Comm. Breeding Product. Milk Anim., Paris, France. Wageningen Acad. Publ., Wageningen, the Netherlands.

Van Soest, P. J. 1994. Nutritional ecology of the ruminant. 2nd ed. Cornell University Press, Ithaca, NY.

Van Soest, P. J., J. B. Robertson, and B. A. Lewis. 1991. Methods for dietary fiber, neutral detergent fiber, and nonstarch polysaccharides in relation to animal nutrition. J. Dairy Sci. 74:3583-3597.

Vencill, W.K., R. L. Nichols, T. M. Webster, J. K. Soteres, C. MallorySmith, N. R. Burgos, W. G. Johnson, and M. R. McClelland. 2012. Herbicide resistance: Toward an understanding of resistance development and the impact of herbicide-resistant crops. Weed Sci. 60(SP1):2-30.

Vlaeminck, B., V. Fievez, A. R. J. Cabrita, A. J. M. Fonseca, and R. J. Dewhurst. 2006. Factors affecting odd- and branched-chain fatty acids in milk: A review. Anim. Feed Sci. Technol. 131:389-417. 